\title{
Challenges and Opportunities of Light-Emitting Diode (LED) as Key to Modulate Antioxidant Compounds in Plants. A Review
}

\author{
Martina Loi ${ }^{1, *,+(\mathbb{C})}$, Alessandra Villani ${ }^{1,2,+}+$ , Francesco Paciolla ${ }^{3}$, Giuseppina Mulè ${ }^{1}$ and Costantino Paciolla ${ }^{2}(\mathbb{C})$ \\ 1 Institute of Sciences of Food Production, National Research Council, Via Amendola 122/O, 70126 Bari, Italy; \\ alessandra.villani@ispa.cnr.it (A.V.); giuseppina.mule@ispa.cnr.it (G.M.) \\ 2 Department of Biology, University of Bari Aldo Moro, Via E. Orabona 4, 70125 Bari, Italy; \\ costantino.paciolla@uniba.it \\ 3 Automation Engineering, Polytechnic of Bari, Via E. Orabona 4, 70125 Bari, Italy; \\ paciollafrancesco0411@gmail.com \\ * Correspondence: martina.loi@ispa.cnr.it; Tel.: +39-08-05-929-329 \\ + These authors contributed equally to this work.
}

check for

updates

Citation: Loi, M.; Villani, A.; Paciolla, F.; Mulè, G.; Paciolla, C. Challenges and Opportunities of Light-Emitting Diode (LED) as Key to Modulate Antioxidant Compounds in Plants. A Review. Antioxidants 2021, 10, 42. https://doi.org/10.3390/ antiox10010042

Received: 16 December 2020 Accepted: 27 December 2020 Published: 31 December 2020

Publisher's Note: MDPI stays neutral with regard to jurisdictional clai$\mathrm{ms}$ in published maps and institutional affiliations.

Copyright: (C) 2020 by the authors. Licensee MDPI, Basel, Switzerland. This article is an open access article distributed under the terms and conditions of the Creative Commons Attribution (CC BY) license (https:// creativecommons.org/licenses/by/ $4.0 /)$.

\begin{abstract}
Plant antioxidants are important compounds involved in plant defense, signaling, growth, and development. The quantity and quality of such compounds is genetically driven; nonetheless, light is one of the factors that strongly influence their synthesis and accumulation in plant tissues. Indeed, light quality affects the fitness of the plant, modulating its antioxidative profile, a key element to counteract the biotic and abiotic stresses. With this regard, light-emitting diodes (LEDs) are emerging as a powerful technology which allows the selection of specific wavelengths and intensities, and therefore the targeted accumulation of plant antioxidant compounds. Despite the unique advantages of such technology, LED application in the horticultural field is still at its early days and several aspects still need to be investigated. This review focused on the most recent outcomes of LED application to modulate the antioxidant compounds of plants, with particular regard to vitamin C, phenols, chlorophyll, carotenoids, and glucosinolates. Additionally, future challenges and opportunities in the use of LED technology in the growth and postharvest storage of fruits and vegetables were also addressed to give a comprehensive overview of the future applications and trends of research.
\end{abstract}

Keywords: food quality; food safety; light-emitting diode (LED); plant antioxidants; polyphenols; postharvest; vitamin C

\section{Introduction}

Plant antioxidants include a wide variety of compounds, which are responsible for essential plant functions, including signaling, defense, oxidative damage prevention, and free-radical scavenging [1]. In addition, some antioxidants are responsible for the color, aroma, and taste of fruits, vegetables, and processed products. Thus, they determine the quality and shelf life of a food, consumers' appreciation, and their economic value [2]. Fruits, vegetables, herbs, and spices are rich in antioxidant compounds, and their consumption in the diet is encouraged, owing to their antioxidant and anti-inflammatory properties, the positive effects on blood pressure, lipids, insulin resistance, and cardiovascular health [3]. Several meta-analyses reported evidence of an inverse correlation between antioxidants in the diet and all-cause mortality [4] and acute coronary syndrome [3], even among high-risk subjects [5], whilst the consumption of specific polyphenols from olives and cocoa was recognized as beneficial to prevent cardiovascular disease [6,7].

Polyphenols, photosynthetic pigments, glutathione, vitamin C (L-ascorbic acid, Vit C) and other vitamins, and antioxidant enzyme systems, such as generic peroxidases, polyphenol oxidases, ascorbate peroxidase (APX), glutathione peroxidase, glutathione reductase (GR), monodehydroascorbate reductase (MDHAR), dehydroascorbate reductase (DHAR), 
thioredoxins, peroxiredoxin, superoxide dismutase, and catalase are among the most important components involved in the modulation of the redox status of the cells and in the response to pathogens and adverse environmental conditions. Several factors are involved in the regulation of the synthesis, turnover, and degradation of such compounds, including both biotic and abiotic stresses, such as light [8-10]. Development, growth, and physiology of the plant depend on the availability of light [11,12]. Light duration (photoperiod), intensity, quality (wavelength), and direction play key roles in plant studies [13].

Through photosynthetic fixation, plants are able to transform the solar energy into reducing equivalents, and $\mathrm{CO}_{2}$ into sugars. However, light is an essential factor driving several biochemical pathways for plant growth and development. In particular, the synthesis and accumulation of antioxidants such as Vit C, phenolic acids, carotenoids, flavonoids, anthocyanins, and $\alpha$-tocopherol in leafy tissues and fruits in many horticultural and herbal crops are driven by the photoperiod, intensity, and quality [14-16]. Light intensity and wavelength vary during the daytime and by season, latitude, and climate and are perceived differently by cells according to the position of the leaf within a canopy and of the cell within a leaf [17].

Light quality and intensity are perceived by plants through different types of photoreceptors, namely, phytochrome (PHY), cryptochrome (CRY), phototropin (PHOT), flavin binding Kelch domain F box protein (FKF1), zeitlupe (ZTL), LOV Kelch protein2 (LKP2), and UV-B resistance locus 8 (UVR8). According to the receptor type, they can be sensitive to both low and high irradiance levels, as well as to specific light wavelengths [18]. Due to such implications, artificial light supplementation has been widely applied in horticulture on economically relevant crops to compensate for short photoperiods, to support photosynthesis, to control plant flowering and pests, and to improve plant nutritional quality [19].

The earliest report of the use of artificial lighting systems dates back to 1868, when the Russian botanist Andrei Famintsyn applied artificial light in plant and microalgae research [20]. Since then, different lighting systems have been used, including fluorescent, high-pressure mercury, high-pressure sodium (HPS), metal-halide lamps, and lightemitting diode (LED).

At present times, LED technology has gained a massive popularity for its ability to produce specific spectra. In fact, compared to other artificial light sources, monochromatic LEDs show unique spectra outputs in terms of wavelengths, along with an equivalent luminous efficacy, lower operational cost, lack of radiant heat, and longer lifespan. Due to these unique advantages, LEDs are now used in controlled environments, e.g., growth chambers, greenhouses, and vertical farming, as well as in the postharvest storage of many vegetables to support plant growth and to specifically stimulate the synthesis of bioactive compounds [21].

LEDs allow studying the light-induced processes and, in particular, the light-dependent (or induced) physio-morphological events that could bring, for instance, increased production of primary and secondary metabolites, or the biosynthesis of novel molecules with health-promoting properties.

However, regulating the production of specific antioxidant compounds by means of LEDs is a complex task. The metabolic pathways are often redundant and regulated at different levels, according to the plant species, tissues, the spectral combination, photoperiods, and irradiances [2,22]. Therefore, this review aims to elucidate LEDs effects on plants metabolism, with particular regard to the content of antioxidant compounds, such as Vit C, phenols, chlorophylls, carotenoids, and glucosinolates.

An overview of the most recent findings in the horticultural field is provided, and the challenges and perspectives of LEDs application at all levels of the supply chain are critically discussed. 


\section{LED Technology}

An LED is a solid-state semiconductor diode, allowing unidirectional current flow from the anode to the cathode within a specific voltage range. The diode is composed of two differently doped materials that jointly form a p-n heterojunction, where the $\mathrm{p}$-side contains excess positive charge (holes), while the n-side contains excess negative charge (electrons). When a positive forward voltage is applied, the current flows from the p-side to the $\mathrm{n}$-side and electrons are forced to move from the n-side toward the $\mathrm{p}$-side, whilst holes make the reverse path. As an electron crosses the depletion layer, near the junction, it recombines with a hole and falls from the conduction band in a lower energy level, the valence band, and releases energy in the form of a photon (Figure 1A). The effect is a form of electroluminescence and incoherent narrow-spectrum light is emitted.

(A)

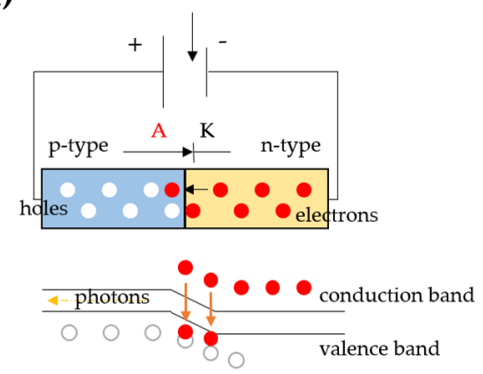

(B)

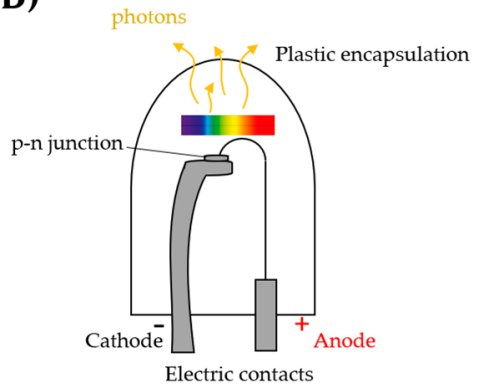

Figure 1. (A) Working principle and (B) structure of a light-emitting diode (LED).

In Figure 1B, the most important parts of an LED are shown. The cathode is connected to the $n$-side of the junction, while the p-side is connected to the anode with a connecting wire.

The emitted light wavelength, so its color, depends on the band gap energy of the junction's materials $[23,24]$. The band gap represents the minimum energy difference between the top of the valence band and the bottom of the conduction band; it depends on the dopants used in the p- and n-sides. An LED is usually made by direct band gap semiconductors, so the top of the valence band and the bottom of the conduction band occur simultaneously; in this way, the probability that an electron spontaneously recombines with a hole is high.

The electron-hole recombination rate $r$ is

$$
r=B n p
$$

where $B$ is a constant and depends on the material properties of the semiconductors being used, and $n$ and $p$ are the concentrations of electrons and holes in atoms $/ \mathrm{cm}^{3}$, respectively.

If the transitions take place in a direct bandgap semiconductor, the emission wavelength $\lambda$ is

$$
\lambda=h c / E_{g}
$$

where $h$ is Planck's constant, $c$ is the speed of light and $E_{g}$ is the energy band gap.

In order to obtain visible radiation, energy gaps have to be greater than about $2 \mathrm{eV}$; unfortunately, materials with such a large gap tend to have high resistivities even when doped.

The most common commercial LEDs require a forward operating voltage approximately between 1.6 and $4 \mathrm{~V}$ with a forward current rating from 10 to $30 \mathrm{~mA}$, with 12 to $20 \mathrm{~mA}$ being the most common range. The spectral densities emitted by LEDs fabricated from various semiconductors and their characteristics are shown (Table 1; Figure 2). The emission spectrum becomes narrower in terms of wavelength as the emission energy moves from the infrared to the ultraviolet ends of the spectrum [25]. 
Table 1. The most representative characteristics for some commercially used LED semiconductors.

\begin{tabular}{|c|c|c|c|c|}
\hline Materials & Formula & Wavelengths [nm] & Light Color & Forward Voltage [V] \\
\hline Gallium-Phosphide & $\mathrm{GaP}$ & \multirow{4}{*}{$610<\lambda<770$} & \multirow{4}{*}{ Red } & \multirow{4}{*}{$1.6-2.0$} \\
\hline Aluminium-Gallium-Arsenide & AlGaAs & & & \\
\hline Gallium-Arsenide-Phosphide & GaAsP & & & \\
\hline Aluminium-Gallium-Indium-Phosphide & AlGaInP & & & \\
\hline Gallium-Phosphide & $\mathrm{GaP}$ & \multirow{3}{*}{$590<\lambda<610$} & \multirow{3}{*}{ Orange } & \multirow{3}{*}{$2.0-2.1$} \\
\hline Gallium-Arsenide-Phosphide & GaAsP & & & \\
\hline Aluminium-Gallium-Indium-Phosphide & AlGaInP & & & \\
\hline Gallium-Arsenide-Phosphide & GaAsP & \multirow[b]{2}{*}{$570<\lambda<590$} & \multirow[b]{2}{*}{ Yellow } & \multirow{2}{*}{$2.1-2.2$} \\
\hline Gallium-Phosphide & $\mathrm{GaP}$ & & & \\
\hline Gallium-Phosphide & $\mathrm{GaP}$ & \multirow{3}{*}{$500<\lambda<570$} & \multirow{3}{*}{ Green } & \multirow{3}{*}{$1.9-4$} \\
\hline Aluminium-Gallium-Phosphide & $\mathrm{AlGaP}$ & & & \\
\hline Aluminium-Gallium-Indium-Phosphide & AlGaInP & & & \\
\hline Silicon carbide as substrate & $\mathrm{SiC}$ & \multirow{2}{*}{$450<\lambda<500$} & \multirow{2}{*}{ Blue } & \multirow{2}{*}{$2.4-3.7$} \\
\hline Zinc Sulfide & $\mathrm{ZnS}$ & & & \\
\hline Gallium-Nitride & $\mathrm{GaN}$ & \multirow{2}{*}{$400<\lambda<450$} & \multirow{2}{*}{ Violet } & \multirow{2}{*}{$2.7-4.0$} \\
\hline Indium-Gallium-Nitride & InGaN & & & \\
\hline Blue diode with yellow phosphor & & Broad spectrum & White & 3.5 \\
\hline
\end{tabular}

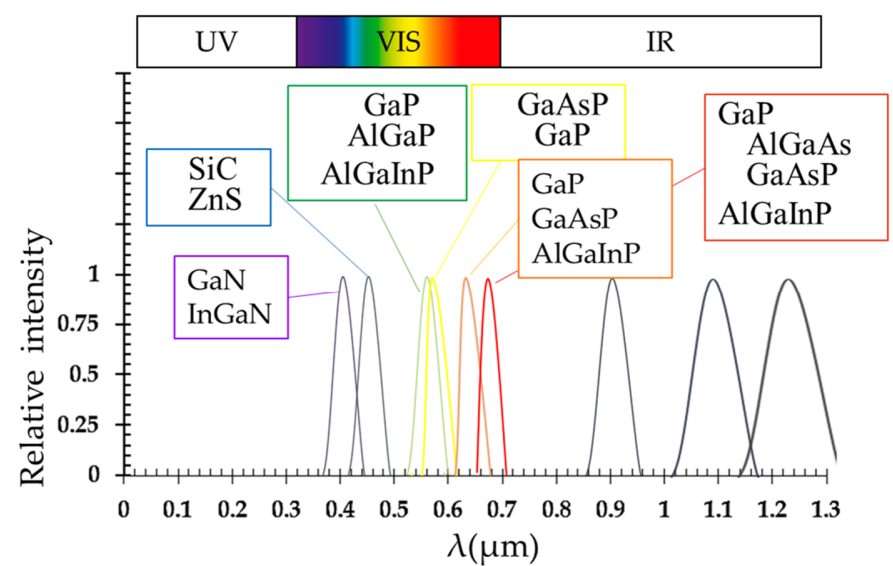

Figure 2. Spectral distribution emitted by an LED fabricated from various semiconductors (adapted from [25]).

There are different performance parameters to compare LEDs. The most important one is the external quantum efficiency $\eta_{E Q E}(\mathrm{EQE})$ which quantifies the conversion efficiency of electrical energy into external optical energy:

$$
\eta_{E Q E}=\eta_{I Q E} \times \eta_{E X T}
$$

where $\eta_{I Q E}$ is the internal quantum efficiency (IQE), which is the ratio between the number of emitted photons from the active region per second and the injected electrons per second, and $\eta_{E X T}$ is the extraction efficiency which represents the ratio between the number of photons generated that escape from the device per second and the number of emitted photons from the active region per second [24].

The IQE of today's best LEDs is at least 75\% and may even be approaching $80 \%$. To make further improvements, nonradiative recombination centers need to be eliminated and a shift to semipolar crystallographic LEDs is needed [26]. Although the IQE is high, the EQE is much lower; the radiation at the semiconductor/air interface will escape only when the incident rays form an angle with the normal to the interface within the cone 
of critical angle $\theta_{c}$, whilst other rays get reflected via total internal reflection (TIR) in the semiconductor (Figure 3). The critical angle is calculated as

$$
\theta_{c}=\sin ^{-1}\left(n_{2} / n_{1}\right) \quad \text { with } n_{2}<n_{1}
$$

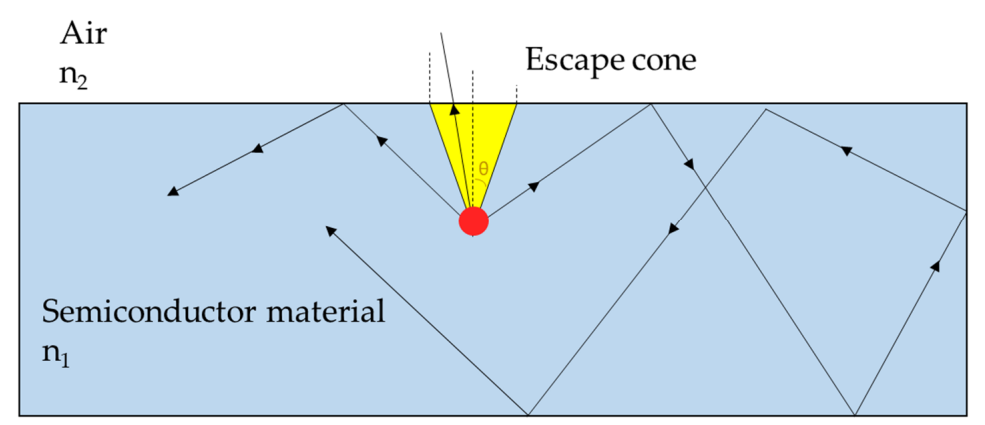

Figure 3. Light escape cone (figure adapted from [27]).

Unfortunately, most of the LED materials are III-V compounds of the periodic table and have high refractive indices giving rise to small critical angles, hence the escape cone is very small. For instance, gallium arsenide-based materials, common for red LEDs, have a very high refractive index $(n=3.4)$ and the escape cone has $\theta_{c}=17.1^{\circ}$ [24], meaning that only about $2 \%$ of the light can escape. One of the most used techniques to widen the escape cone and increase the EQE is to surround the junction in a transparent plastic encapsulation $\left(n_{2}=1.5\right)$.

\section{Plant Photoreceptors}

Plants utilize light to produce energy by the photosynthetic process and to obtain information on the habitat where they live. The perception of the light stimulus is made possible by the photoreceptors, specialized proteins able to perceive specific wavelengths of spectra light, from 250 to $750 \mathrm{~nm}$.

In the Brassicaceae Arabidopsis thaliana, a model plant organism, four main classes of photoreceptors were described: PHYs, which perceive red light (RL, absorption peak of $\sim 660 \mathrm{~nm}$ ) and far red light (FR, absorption peak of $\sim 730 \mathrm{~nm}$ ) [28], CRYs [29], PHOTs [30], and three recognized LOV/F-box/Kelch-repeat proteins, namely, ZTL, FKF1, and LKP2 [31,32], which absorb ultraviolet A radiation (UV-A, $\sim 315-400 \mathrm{~nm}$ ) or blue light (BL) $(\sim 400-500 \mathrm{~nm}$, with a peak of absorption $\sim 470 \mathrm{~nm})$. In addition, one UV-B $(\sim 280-315 \mathrm{~nm})$ photoreceptor, called UVR8, was identified [33,34] (Figure 4). So far, in Arabidopsis, five different phytochromes have been identified, namely, PHY A, B, C, D, and E. PHY B perceives RL $(660 \mathrm{~nm})$ that converts the physiological inactive form of the Pr phytochrome into a physiological active form of the Pfr phytochrome and triggers different physiological processes. PHY B controls physiological responses known as escape from shade, in which transcriptional factors called phytochrome interacting factors (PIFs) regulate the expression of the genes involved, according to the R/FR ratio. In addition, PHYs regulate the flowering, senescence, etiolation, and de-etiolation. BL is mainly perceived by three receptor families: CRYs, PHOTs, and ZTLs [35]. By these photoreceptors, BL modulates various processes, such as phototropism, chloroplast relocation, stomatal opening, rapid inhibition of hypocotyl elongation, and leaf expansion [36]. In Arabidopsis, there are three different cryptochromes: CRY1, CRY2, and CRY3. CRY1 and CRY2 proteins are involved in de-etiolation, which is BL intensity-dependent [37].

Together with phytochromes, CRYs are involved in the escape from shade (canopy shade) [38], whilst all blue photoreceptors are involved in the circadian rhythm. Many metabolic activities show a circadian rhythm and therefore they are regulated by endogenous factors, namely, oscillators, that supervise the rhythm also in absence of external stimuli [39]. For instance, the flowering is influenced by the photoperiod and the hours of 
light are fundamental for the plant to perceive the seasonal variations and to flower in a favorable annual period.

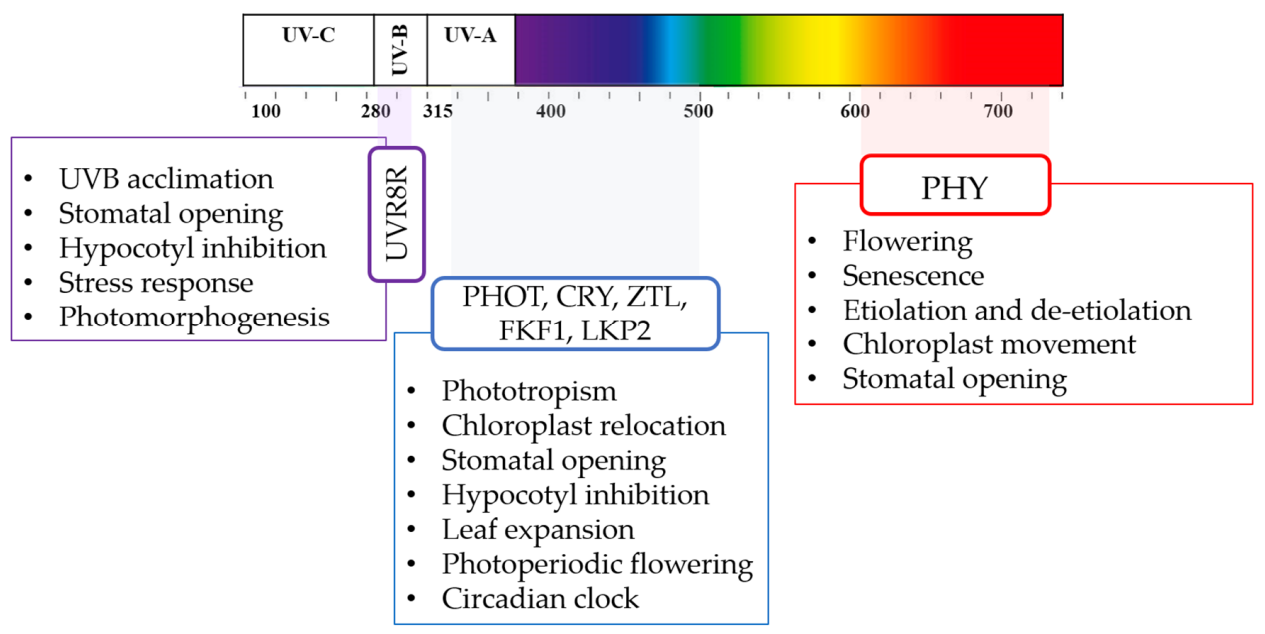

Figure 4. Light spectra, plant photoreceptors, and main light-driven physiologic plant response. Ultraviolet radiation A (UVA), ultraviolet radiation B (UV-B), ultraviolet radiation C (UV-C), phytochrome (PHY), cryptochrome (CRY), phototropin (PHOT), flavin binding Kelch domain F box protein (FKF1), zeitlupe (ZTL), LOV Kelch protein2 (LKP2), and UV-B resistance locus 8 (UVR8).

There are two PHOTs in Arabidopsis, namely, PHOT1 and PHOT2. Both regulate the phototropism in elevated BL intensity $\left(1-100 \mu \mathrm{mol} \mathrm{m}{ }^{-2} \cdot \mathrm{s}^{-1}\right)$, while PHOT1 also regulates in low BL intensity $\left(0.01-1 \mu \mathrm{mol} \mathrm{m} \mathrm{m}^{-2} \cdot \mathrm{s}^{-1}\right)$ [40]. By modulating the stomatal opening, the phototropins also regulate $\mathrm{CO}_{2}$ uptake and transpiration (PHOT1 and PHOT2) and modulate chloroplast movements (PHOT2). FKF1 is essential for photoperiodic-specific light signaling in Arabidopsis [41] and F-box proteins FKF1 and LKP2 act synergistically with ZTL to control Arabidopsis clock progression [42]. UVR8 mediates UV-B photomorphogenic responses, securing plant acclimation and thus promoting plant survival and photoprotection in sunlight [33]. Generally, all photoreceptors perceive, interpret, and transduce light signals via distinct intracellular signaling pathways, by means of which the photoresponsive nuclear gene expression is regulated, finally leading to adaptive changes at the cell and whole organism levels [43].

Interestingly, as in nature, the lighting conditions are very dynamic and changing, and plants are able to perceive RL, BL, and FR light at the same time. In this way, plants are able to create a balance between growth, yield, and the accumulation of compounds with antioxidant activity. Studying the interplays of the photoreceptors-mediated signaling transduction pathways could bring researchers to a better understanding of the molecular mechanisms of such interactions and of the processes they regulate. A useful experimental approach for this study could exploit LEDs, which enable the use of selected wavelengths and intensities. From a practical point of view, the biggest challenge is to design an LED protocol which can be modulated to follow the plant through its phenological stages and provide stimuli to the growth, the development of plant biomass, or the accumulation of antioxidant compounds when needed. The recent advancements of LED technologies provide abundant opportunities to study those various plant light responses to monochromatic or specific light combinations, especially with regard to the antioxidant and phytonutrient compounds of plants [44].

\section{LED Effects on the Antioxidants and Phytonutrients of Plants}

\subsection{Vitamin C}

Vit $C$ is an important antioxidant compound which is ubiquitous in the plant kingdom. It is a natural water-soluble vitamin with a low molecular weight (176.12 Da) and possesses numerous functions in plants [45-48]. In plants, Vit C is involved in growth and devel- 
opment processes and, in particular, in the synthesis of plant hormones, in cell division, cell elongation, and cell differentiation, in programmed cell death, in photosynthesis, and in iron uptake, as well as in defense response against biotic and abiotic stresses $[45,48,49]$. The major pathway of ascorbate synthesis in higher plants is the L-galactose pathway (Figure S1) [48,50]. In humans, Vit C is a potent reducing and antioxidant agent that is involved in the formation of collagen in fibrous tissue, teeth, bones, connective tissue, skin, and capillaries. Furthermore, it is involved in detoxifying reactions and can prevent bacterial infections [51]. Vit C cannot be produced or stored by humans; therefore, it must be assumed with vegetables and fruits in the diet. The best dietary sources include green pepper, strawberries, oranges, and blackcurrants, which contain approximatively 60-100 mg/100 g of fresh weight [52]. Light can control Vit C accumulation through different types of regulation [48]. Vit C synthesis is light-dependent, as reported in Phaseolus vulgaris leaves [53], oat (Avena sativa L., cv. Roga) leaves [54], postharvest broccoli (Brassica oleracea L. var. italica) [55,56], green asparagus (Asparagus officinalis L. var. UC157) [57], soybean (Glicine max L. Merr), mung bean (Vigna radiata L. Wilczek), radish (Raphanus sativus L.), and pumpkin (Cucurbita moschata Duch) sprouts [58]. Its synthesis depends on the intensity and quality of light, as well as exposure time. Consequently, diurnal variations were observed $[59,60]$. A strong daily change in transcript levels of enzymes of the Vit C biosynthetic pathway was reported in tomato leaves (11 of the 12 studied genes showed significant changes in their expression pattern). Among these genes, a diurnal variation in transcript levels of VTC2 (coding for GDP-L-galactose phosphorylase) and GME1 (coding for GDP-D-mannose 3',5'-epimerase) was correlated with the leaf Vit C content [61]. On the other hand, darkness promotes Vit $C$ catabolism [62]. Increased Vit $C$ accumulation was found in plants grown in open fields with respect to those grown in greenhouses [61] and in sun-illuminated leaves [63]. The constitutive photomorphogenesis 9 (COP9) signalosome (CSN) is one of the main factors involved in Vit C synthesis: it is a photomorphogenic complex of the ubiquitin-proteasome pathway, involved in the degradation of the enzymes involved in ascorbate synthesis in the dark through regulation of E3 ligase activity [64]. As the synthesis of Vit $C$ and the photosynthetic process are strictly correlated, light could influence the Vit C levels by stimulating the photosynthetic process. In fact, soluble carbohydrates are the main photosynthetic products and, at the same time, the precursors of Vit C [65,66]. In contrast, Ntagkas and coworkers [67] showed that in tomato fruits, light induced Vit $C$ accumulation independently from carbohydrate availability, suggesting that other mechanisms may have a significant impact on Vit $C$ synthesis.

Various roles in the regulation of the photosynthetic process have been attributed to Vit C, particularly in the acclimation to high light, as demonstrated in ascorbate-deficient mutants of Arabidopsis [68] and in transgenic tobacco lines (Nicotiana tabacum) [69] when grown under high irradiance levels. The content of Vit $C$ depends upon the activity of the enzymes involved in its biosynthesis and oxidation, and both have been reported to be influenced by LEDs [70,71]. BL and RL were the most used LEDs to increase Vit C content in different fruits and vegetables; fewer studies have focused on other LED types, such as green (GL) or yellow (YL) LEDs.

BL treatment effectively increased the Vit $C$ content in the juice sacs of three citrus varieties: satsuma mandarin (Citrus unshiu Marc.), Valencia orange (C. sinensis Osbeck), and Lisbon lemon (C. limon Burm.f.). In addition, continuous irradiation was more effective than pulsed irradiation. Particularly, Vit C accumulation by BL treatment was highly regulated at the transcription level with the up-regulation of Vit $\mathrm{C}$ biosynthetic genes (CitVTC1, CitVTC2, CitVTC4, and CitGLDH), regeneration genes (CitMDAR1, CitMDAR2, and CitDHAR), and two glutathione-producing genes (CitGR and CitchGR) [72].

Postharvest irradiation of RL was optimal for delaying the senescence and increasing Vit C content in leaves of pack choi (Brassica rapa ssp. Chinensis). Gene expression analysis revealed that the VTC2 biosynthetic gene was 2.54- and 1.32-fold up-regulated after two and four days of RL treatment, respectively, and was down-regulated after dark and FR light treatments; the VTC4 gene also exhibited a relatively higher expression after RL 
treatment. The authors concluded that RL might also promote Vit C biosynthesis, at least at the early stage of storage, while BL treatment had little effect on Vit C content [73]. Gene expression analysis confirmed that RL treatment promoted the expression of BraVTC2, the putative homologous gene of AtVTC2 encoding a key Vit C biosynthetic enzyme in Arabidopsis [74]. Conversely, in another brassica species, namely, broccoli (Brassica oleracea L. var. italica), RL effectively suppressed the decrease in Vit C after harvest, whereas BL had no effect on the metabolism of Vit $C$. The up-regulation of two Vit $C$ biosynthetic genes (BO-VTC2 and BO-GLDH) and two Vit C regeneration genes (BO-MDAR1 and BO-MDAR2) contributed to the higher Vit $C$ content in the modified white light (WL) treatment on the first and second days after harvest [55]. BL proved to be more efficient than RL in strawberry (Fragaria ananassa Duch. Cv. Fengguang), which showed higher Vit C content, ascorbate peroxidase activity, and other antioxidant enzymes activities when stored under BL [75].

Changes in levels of Vit $C$ in many vegetables have been observed as a response to the use of single as well as combined spectral LEDs. Supplementing GL with RL plus BL reduced the Vit C content of green leaf lettuce (Lactuca sativa L. cv. Lvdie) by $44 \%$ compared to RL plus BL. In purple leaf lettuce (Lactuca sativa L. cv. Ziya) grown under WL plus RL, no significant differences were observed in Vit C content compared with WL [76]. In lettuce plants under continuous light for 12 days, the ratio 25RL/75BL increased the Vit C level mainly by promoting Vit $\mathrm{C}$ regeneration rather than its biosynthesis. In this case, only the expression of regeneration genes (APX, MDHAR, DHAR, and GR) was significantly increased [77]. The concentration of Vit $C$ was greater in non-heading Chinese cabbage (Brassica campestris L) seedlings under BL plus RL, followed by those grown under BL, and fluorescent lamps [78]. This is consistent with reports by [79] and [80]. A significant increase in Vit C concentration was found in sprouted seeds of lentil (Lens esculenta Moenh.) and wheat (Triticum aestivum L.) under LED spectra supplemented with GL and in radish (Raphanus satious L.) sprouts grown with supplemental amber (595 nm) light [81].

Furthermore, the irradiance level has been shown to have a great impact on Vit C content. Detached tomato (Solanum lycopersicum) fruits treated with different irradiance levels in a climate-controlled environment contained 32\% more Vit C compared to the fruits kept at lower irradiances or in darkness [82].

On the other hand, GL and YL effects have been scarcely investigated. Vit C content and shoot biomass have been examined in crisphead lettuce (Lactuca sativa L. var. capitata) by using GL, which has a lower light absorptance but greater light transmittance in leaves. The Vit C content was high in crisphead lettuce, especially under GL irradiation because of the deeper light transmittance [83]. When apple peel, tomato, and red bell pepper fruit were irradiated with YL, there was no significant increase in Vit C content compared to the control samples stored in the dark [84].

As shown in Table 2, few studies evaluated the effect of different wavelengths. The effects of different LEDs were investigated with the aim of maintaining freshness and nutrition in cabbage (Brassica rapa) stored at $4-5{ }^{\circ} \mathrm{C}$ for 18 days. Vit $\mathrm{C}$ content was highest for BL, followed by WL, GL, RL, and a non-irradiated control group. Conversely, Loi and coworkers [56] found that GL was the most efficient LED to improve the Vit C profile in broccoli (Brassica oleracea var. italica) during postharvest storage, followed by RL and YL [56]. Although these results are not fully comparable, they may suggest that LED colors have different effects also within the same species [85]. Further details about the Vit C biosynthetic pathway and light gene regulation are shown in Figure S1.

\subsection{Polyphenols}

Polyphenols are a widespread group of phytochemicals characterized by the presence of one or more hydroxylated aromatic rings; they are generally subgrouped into phenolic acids, stilbenes, flavonoids, lignans, and ellagic acids [86]. Even though their chemical structure may differ significantly, their synthesis originates from a common intermediate, phenylalanine, obtained through the shikimate pathway (Figure S2). The key enzymes involved in this pathway are the 3-deoxy-D-arabino-heptulosonate 7-phosphate, the DAHP 
synthase (DS), and the chorismate mutase (CM). Phenylalanine can be converted into phenolic compounds in the phenylpropanoid pathway through the action of another key enzyme, the phenylalanine ammonia lyase (PAL). Those enzymes can be regulated at different levels, including by reactive oxygen species (ROS) deriving from excess light [87] and the activity of light-responsive transcription factors [88].

Polyphenols participate in the plant's defense system against heavy metals, salinity, drought, extreme temperature, pesticides, and UV radiations. In particular, exposure to UV-B radiation stimulates the synthesis and accumulation of polyphenols in the epidermal tissues, where they absorb both visible (anthocyanins) and UV light (anthocyanins and flavonoids) to protect the mesophyll from photooxidation [89,90]. Fruits are among the polyphenol-richest plant tissues and may contain as much as $200-300 \mathrm{mg}$ of polyphenols per $100 \mathrm{~g}$ of fresh weight. Besides providing defense from oxidation, they contribute to the aroma and color, together with the high antioxidant activity, of such products [86].

LEDs have been used to increase polyphenol content, with particular regard to flavonoids. BL, RL, and FR are among the most studied monochromatic LEDs and have shown to be able to increase the total phenol content (TPC) and total flavonoid content (TFC) in different commodities, when applied during germination of sprouts [91,92], plant growth [93-95], or in the postharvest storage [56,96]. More specifically, BL has often been reported to increase the content of simple phenols, such as chlorogenic, gallic, ferulic, p-coumaric, caffeic, hydroxybenzoic, and benzoic acids. [95-97]. Similarly, BL was reported to increase the flavonoids contents, e.g., chalcone, naringenin, quercetin [95], kaempferol, rutin, (+)-catechin, (-)-epicatechin, cyanidin glucosides, and resveratrol [96-100], but also to reduce the content of rutin [99], quercetin, and other flavonoids [95]. During postharvest, RL and BL maintained the levels of different flavonoids, e.g., diosmin, hesperidin, didymin, neoeriocitrin, and narirutin [96]. RL and YL were reported to stimulate the accumulation of simple phenols, such as of $p$-hydroxybenzoic acid, caffeic acid, $p$-coumaric acid, ferulic acid, and flavonoids, such as rutin and resveratrol, though to a lesser extent than BL [98].

Despite the majority of the studies being only focused on the measurement of the TPC, $\mathrm{TFC}$, or of specific phenolic compounds, few of them also reported that these increments after $\mathrm{WL}, \mathrm{BL}$, and RL treatments were due to the increased activity of the key enzymes of the shikimate and phenylpropanoid pathways, such as PAL [101,102], chalcone synthase (CHS), chalcone isomerase (CHI), or in flavonoid and anthocyanin synthesis pathways, such as flavonol synthase (FLS), leucoanthocyanidin dioxygenase (LDOX), dihydroflavonol 4-reductase (DFR), and stilbene synthase (STS) (for more details, see Figure S2) [103-105]. The synthesis of phenolic compounds is regulated by structural genes, transcriptional activators, and repressors, the latter two acting on putative light regulatory units in gene promoters [106]. In addition, the synthesis of phenolic compounds was shown to be supported by an increased production of phenylalanine opposed to tryptophan. This means that the regulation of TPC and TFC by LEDs can be performed directly by inducing the expression of the key enzyme and indirectly by increasing the precursor molecule [95]. The results of the many different studies in the literature generally agreed on the role of BL and RL as stimulating LEDs, whilst GL was less effective [94,102,107] or ineffective [56]. Despite that Loi and colleagues did not detect a significant increase in phenolic compounds in broccoli [56], a positive effect was registered by Jin and colleagues, who used the same wavelength but a 2-fold intensity [108], proving that light intensity also plays an important role $[95,109]$. Generally, higher light intensities were more effective than low intensities in inducing light-responsive genes and increasing the polyphenol content in plants. Nonetheless, results also depend upon plant species [15,93], cultivars [101,110], and timing of LED exposure [111]. Most importantly, each polyphenolic compound has a specific response to light quality [91]. Thus, establishing whether light intensity is more determinant than light quality or vice versa is quite challenging; further efforts should be dedicated at designing experiments which encompass the use of different light qualities at different intensities and a comprehensive evaluation of the antioxidant compounds in specific cultivars. The most recent studies are reported in Table 3. 
Table 2. LED effects on the vitamin C (Vit C) content of different plants. Blue light (BL), red light (RL), green light (GL), yellow light (YL), white light (WL).

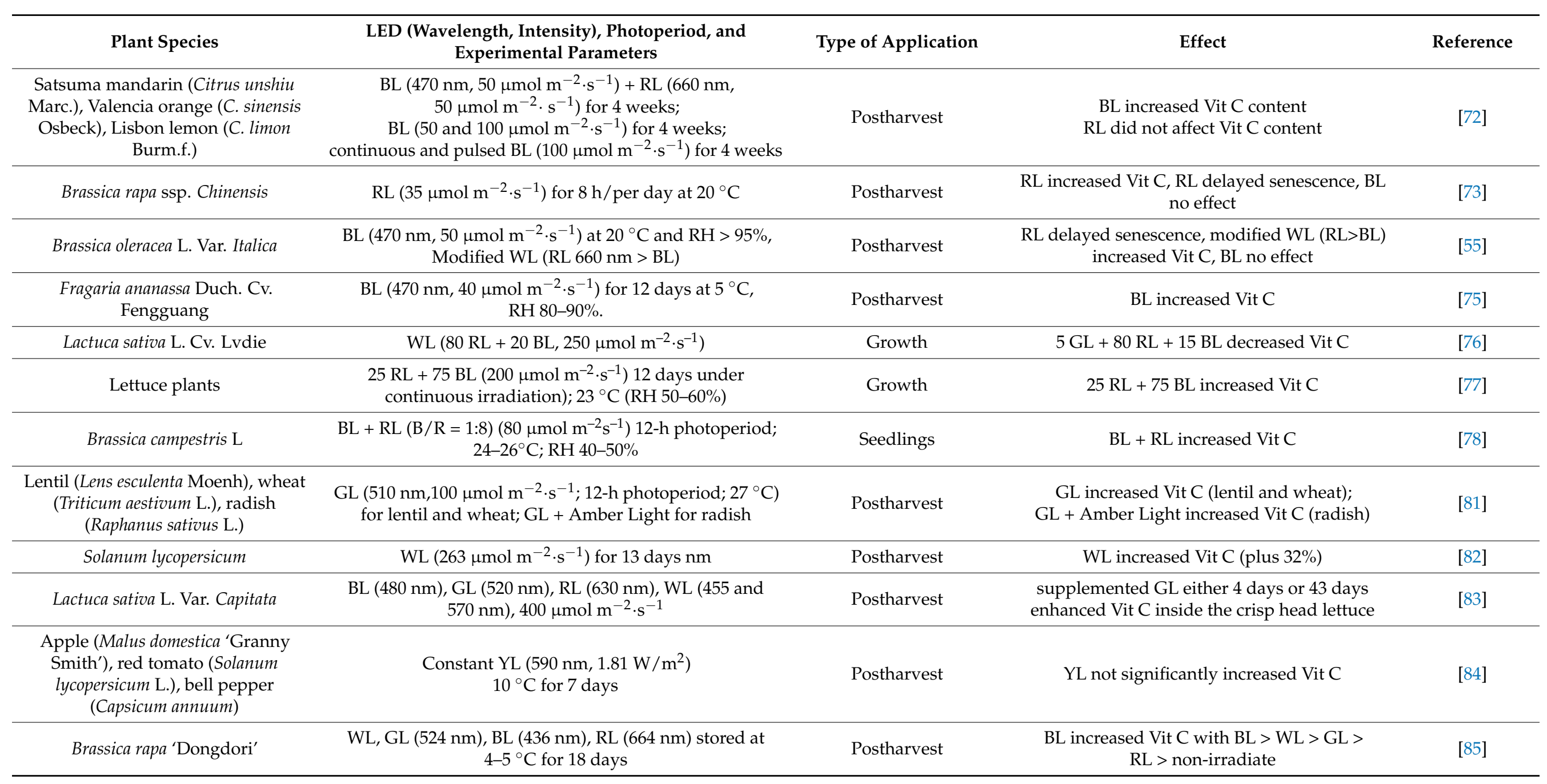




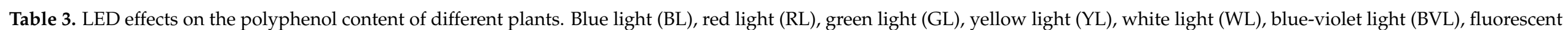

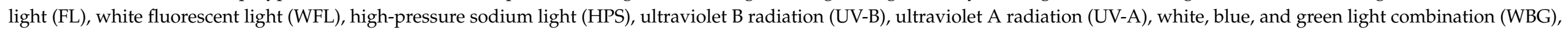
total phenolic compounds (TPC), total flavonoid compounds (TFC).

\begin{tabular}{|c|c|c|c|c|}
\hline Plant Species & $\begin{array}{c}\text { LED (Wavelength, Intensity), Photoperiod, and } \\
\text { Experimental Parameters }\end{array}$ & $\begin{array}{c}\text { Type of } \\
\text { Application }\end{array}$ & Effect & Reference \\
\hline $\begin{array}{l}\text { Broccoli (Brassica oleracea } \\
\text { L. Var. Italica) }\end{array}$ & $\begin{array}{c}\text { BL }\left(467 \mathrm{~nm}, 21 \mu \mathrm{mol} \mathrm{m}{ }^{-2} \cdot \mathrm{s}^{-1}\right) \\
\text { GL }\left(522 \mathrm{~nm}, 24 \mu \mathrm{mol} \mathrm{m}{ }^{-2} \cdot \mathrm{s}^{-1}\right), \mathrm{YL}(587 \mathrm{~nm}, \\
\left.27 \mu \mathrm{mol} \mathrm{m}{ }^{-2} \cdot \mathrm{s}^{-1}\right) \operatorname{RL}\left(625 \mathrm{~nm}, 66 \mu \mathrm{mol} \mathrm{m}{ }^{-2} \cdot \mathrm{s}^{-1}\right) \mathrm{WL} \\
\left(3000 \mathrm{~K} \mathrm{color} \text { temperature, } 40 \mu \mathrm{mol} \mathrm{m} \mathrm{m}^{-2} \cdot \mathrm{s}^{-1}\right) ; \text { continuous } \\
\text { irradiation at } 4^{\circ} \mathrm{C}\end{array}$ & Postharvest & RL $>\mathrm{YL}>\mathrm{BL}$ increased the TPC throughout the storage period & [56] \\
\hline $\begin{array}{l}\text { Brussels sprouts (Brassica } \\
\text { oleracea var. gemmifera) }\end{array}$ & $\begin{array}{l}\text { UV-B }\left(300 \mathrm{~nm}, 0.02 \mu \mathrm{mol} \mathrm{m}{ }^{-2} \cdot \mathrm{s}^{-1}\right), \text { UV-A }(365 \mathrm{~nm}, \\
\left.14 \mu \mathrm{mol} \mathrm{m}{ }^{-2} \cdot \mathrm{s}^{-1}\right), B L\left(470 \mathrm{~nm}, 11 \mu \mathrm{mol} \mathrm{m}{ }^{-2} \cdot \mathrm{s}^{-1}\right) \\
\text { RL }\left(660 \mathrm{~nm}, 2 \mu \mathrm{mol} \mathrm{m}{ }^{-2} \cdot \mathrm{s}^{-1}\right) ; 16-\mathrm{h} \text { photoperiod }\end{array}$ & Sprouting & Compound specific effects & [91] \\
\hline $\begin{array}{l}\text { Buckwheat sprouts } \\
\quad \text { (Fagopyrum } \\
\text { esculentum Moench) }\end{array}$ & $\begin{array}{l}\text { BL (460nm), RL (625nm), FL }\left(35 \mu \mathrm{mol} \mathrm{m}{ }^{-2} \cdot \mathrm{s}^{-1}\right) ; 16 \mathrm{~h} \text { of } \\
\text { light; supplement and } 8 \mathrm{~h} \text { of dark per day }\end{array}$ & Sprouting & $\begin{array}{c}\mathrm{BL}>\mathrm{RL}>\mathrm{FL} \text { increasedTPC, TFC, and antioxidant capacity using ABTS } \\
\text { radical cation assay. BL increased orientin, isoorientin, vitexin, } \\
\text { isovitexin, rutin, and quercetin-3-O-robinobioside }\end{array}$ & [92] \\
\hline $\begin{array}{l}\text { Basil (Ocimum basilicum), } \\
\text { arugula (Eruca sativa), } \\
\text { and bloody dock } \\
\text { (Rumex sanguineus) }\end{array}$ & $\begin{array}{l}\text { BL }\left(450 \mathrm{~nm}, 300 \mu \mathrm{mol} \mathrm{m}^{-2} \cdot \mathrm{s}^{-1}\right), \text { BVL }(440-420 \mathrm{~nm}, \\
\left.\quad 300 \mu \mathrm{mol} \mathrm{m}{ }^{-2} \cdot \mathrm{s}^{-1}\right), \mathrm{HPS}(600 \mathrm{~nm}, 400 \mathrm{~W})\end{array}$ & Growth & $\begin{array}{c}\text { BL and BVL increased the phenolic acid content in basil, BV the } \\
\text { flavonoids in arugula. No increase was registered in bloody dock with } \\
\text { either BL or BV }\end{array}$ & [93] \\
\hline $\begin{array}{l}\text { Cherry tomato seedlings } \\
\text { (Solanum lycopersicum } \\
\text { L. 'Cuty') }\end{array}$ & $\begin{array}{l}\text { RL }\left(655 \mathrm{~nm}, 200 \mu \mathrm{mol} \mathrm{m}{ }^{-2} \cdot \mathrm{s}^{-1}\right), \mathrm{BL}(456 \mathrm{~nm}, \\
\left.200 \mu \mathrm{mol} \mathrm{m}{ }^{-2} \cdot \mathrm{s}^{-1}\right), \mathrm{GL}\left(518 \mathrm{~nm}, 200 \mu \mathrm{mol} \mathrm{m}{ }^{-2} \cdot \mathrm{s}^{-1}\right) \\
\text { WL }\left(456 \mathrm{~nm}, 200 \mu \mathrm{mol} \mathrm{m}{ }^{-2} \cdot \mathrm{s}^{-1}\right)\end{array}$ & Growth & $\mathrm{BL}>\mathrm{WL}>\mathrm{RL}>\mathrm{GL}$ increased the TPC and TFC & [94] \\
\hline $\begin{array}{l}\text { Tea (Camellia sinensis cv. } \\
\quad \text { Fujian Shuixian) }\end{array}$ & $\begin{array}{c}\text { BL }(450 \mathrm{~nm}) \text { at low }\left(50 \mu \mathrm{mol} \mathrm{m}{ }^{-2} \cdot \mathrm{s}^{-1}\right) \text { medium } \\
\left.(100 \mu \mathrm{mol} \mathrm{m})^{-2} \cdot \mathrm{s}^{-1}\right) \text { and high }\left(200 \mu \mathrm{mol} \mathrm{m}^{-2} \cdot \mathrm{s}^{-1}\right) \\
\text { intensity, WL }\left(100 \mu \mathrm{mol} \mathrm{m} \mathrm{mol}^{-2} \cdot \mathrm{s}^{-1}\right) ; 12-\mathrm{h}_{\text {photoperiod, }} \\
14 \text { days }\end{array}$ & Growth & $\begin{array}{c}\text { High-intensity BL down-regulated several genes involved in flavonoid } \\
\text { biosynthesis; no effects elicited by low- and medium-intensity BL. BL } \\
\text { increased the levels of } 3^{\prime}, 5,6 \text {-trihydroxy-3,4',7,8-tetramethoxyflavone } \\
\text { 3-glucoside, galangin 3-[galactosyl-(1-4)-rhamnoside], and } \\
\text { neocarthamin, and reduced the levels of 3-(2-caffeoylsophoroside) } \\
\text { 7-glucoside, quercetin 3-(4'-acetylrhamnoside) 7-rhamnoside, and } \\
\text { spinacetin 3-(2'-feruloylgentiobioside }\end{array}$ & [95] \\
\hline
\end{tabular}


Table 3. Cont.

\begin{tabular}{|c|c|c|c|c|}
\hline Plant Species & $\begin{array}{l}\text { LED (Wavelength, Intensity), Photoperiod, and } \\
\text { Experimental Parameters }\end{array}$ & $\begin{array}{c}\text { Type of } \\
\text { Application }\end{array}$ & Effect & Reference \\
\hline $\begin{array}{l}\text { Navel oranges (Citrus } \\
\text { sinensis Osbeck) }\end{array}$ & $\begin{array}{c}\text { UVC }\left(10-280 \mathrm{~nm}, 100 \mu \mathrm{mol} \mathrm{m}-2 \cdot \mathrm{s}^{-1}\right), \mathrm{UVB}(270-315 \mathrm{~nm}, \\
\left.100 \mu \mathrm{mol} \mathrm{m}{ }^{-2} \cdot \mathrm{s}^{-1}\right), \mathrm{UVA}(315-400 \mathrm{~nm}, \\
\left.100 \mu \mathrm{mol} \mathrm{m}{ }^{-2} \cdot \mathrm{s}^{-1}\right), \mathrm{BL}\left(470 \mathrm{~nm}, 200 \mu \mathrm{mol} \mathrm{m}{ }^{-2} \cdot \mathrm{s}^{-1}\right) \\
\text { RL }\left(660 \mathrm{~nm}, 150 \mu \mathrm{mol} \mathrm{m}{ }^{-2} \cdot \mathrm{s}^{-1}\right), \mathrm{WL}\left(100 \mu \mathrm{mol} \mathrm{m}^{-2} \cdot \mathrm{s}^{-1}\right) \\
\text { Continuous irradiation for } 6 \text { days; sampling after } 0,6 \\
\text { and } 15 \text { days }\end{array}$ & Postharvest & $\begin{array}{l}\text { BL and RL retained more PC during the irradiation period, while WL, } \\
\text { UVB, and UVC stimulated their accumulation after the irradiation } \\
\text { period. RL and BL maintained the levels of diosmin, diosmetin } \\
\text { 6,8-di-C-glucoside, hesperidin, didymin, neoeriocitrin, and narirutin; } \\
\text { all Uvs increased narirutin, neoeriocitrin, and didymin }\end{array}$ & [98] \\
\hline $\begin{array}{l}\text { Okra (Abelmoschus } \\
\text { esculentus L.) }\end{array}$ & $\begin{array}{l}\mathrm{RL}\left(630 \mathrm{~nm}, 17.28 \mathrm{~W} / \mathrm{m}^{2}\right), \mathrm{BL}\left(470 \mathrm{~nm}, 17.28 \mathrm{~W} / \mathrm{m}^{2}\right) \\
\text { GL }\left(560 \mathrm{~nm}, 17.28 \mathrm{~W} / \mathrm{m}^{2}\right) ; 8 \text { - } \mathrm{h} \text { photoperiod }\end{array}$ & Postharvest & $\begin{array}{l}\text { WL and BL increased the TFC content and the activity of key enzymes } \\
\text { involved in the biosynthesis of phenolics }\end{array}$ & [102] \\
\hline $\begin{array}{l}\text { Bananas (Musa acuminata } \\
\text { cv. Berangan) }\end{array}$ & $\begin{array}{c}\text { BL }\left(464-474 \mathrm{~nm}, 3920 \mu \mathrm{mol} \mathrm{m}^{-2} \cdot \mathrm{s}^{-1}\right), \mathrm{GL}(515-525 \mathrm{~nm}, \\
\left.4340 \mu \mathrm{mol} \mathrm{m} \mathrm{m}^{-2} \cdot \mathrm{s}^{-1}\right) \text { equivalent to photosynthetic intensity } \\
\text { of } 100 \mathrm{~W} \mathrm{~m}^{-2}, \mathrm{RL}\left(617-627 \mathrm{~nm}, 5200 \mu \mathrm{mol} \mathrm{m}^{-2} \cdot \mathrm{s}^{-1}\right) \\
\text { continuous irradiation for } 8 \text { days }\end{array}$ & Postharvest & BL was more effective than RL and GL in increasing in TPC & [107] \\
\hline $\begin{array}{l}\text { Broccoli (Brassica oleracea } \\
\text { L. Var. Italica cv. Chaoda } \\
\text { No. 1) }\end{array}$ & $\begin{array}{l}\text { WFL (300-700nm, }\left(12-13 \mu \mathrm{mol} \mathrm{m}{ }^{-2} \cdot \mathrm{s}^{-1}\right), \mathrm{GL}(520 \mathrm{~nm}, \\
\left.12-13 \mu \mathrm{mol} \mathrm{m}{ }^{-2} \cdot \mathrm{s}^{-1}\right) ; 12-\mathrm{h} \text { photoperiod }\end{array}$ & Postharvest & GL increased the TPC & [108] \\
\hline $\begin{array}{l}\text { Red leaf lettuce (Lactuca } \\
\text { sativa L., cv. Sunmang) } \\
\text { and green leaf lettuce } \\
\text { (Lactuca sativa L., cv. } \\
\text { Grand Rapid TBR) }\end{array}$ & $\begin{array}{l}\text { Various combinations of BL }(456 \mathrm{~nm}) \text { and RL }(655 \mathrm{~nm}) \text { BL: } \\
\text { RL }=0: 100 \%, 13 \%: 87 \%, 26 \%: 74 \%, 35 \%: 65 \%, 47 \%: 53 \% \\
59 \%: 41 \%,\left(171 \mu \mathrm{mol} \mathrm{m}{ }^{-2} \cdot \mathrm{s}^{-1}\right), 12-\mathrm{h} \text { photoperiod }\end{array}$ & Postharvest & $\begin{array}{c}\text { Intermediate BL/RL ratios (35\%:65\% }>47 \%: 53 \%>59 \%: 41 \% \text { in cv. } \\
\text { Sunmang) stimulated the accumulation of TPC }\end{array}$ & [110] \\
\hline
\end{tabular}


Table 3. Cont.

\begin{tabular}{|c|c|c|c|c|}
\hline Plant Species & $\begin{array}{l}\text { LED (Wavelength, Intensity), Photoperiod, and } \\
\text { Experimental Parameters }\end{array}$ & $\begin{array}{c}\text { Type of } \\
\text { Application }\end{array}$ & Effect & Reference \\
\hline $\begin{array}{l}\text { Pea sprouts (Pisum } \\
\text { sativum } \mathrm{L} .)\end{array}$ & $\begin{array}{l}\mathrm{RL}(635 \mathrm{~nm}), \mathrm{BL}(460 \mathrm{~nm}), \mathrm{YL}(585 \mathrm{~nm}), \mathrm{WL} \\
\quad\left(30 \mu \mathrm{mol} \mathrm{m}{ }^{-2} \cdot \mathrm{s}^{-1}\right) ; 12-\mathrm{h} \text { photoperiod }\end{array}$ & Sprouting & $\begin{array}{l}\text { BL was more effective than WL, RL, and YL in increasingd the TPC and } \\
\text { TFC with respect to the dark. BL increased the content of chlorogenic } \\
\text { acid, } p \text {-hydroxybenzoic acid, caffeic acid, gallic acid, } p \text {-coumaric acid, } \\
\text { ferulic acid, rutin, and resveratrol; WL increased the content of } \\
\text { chlorogenic acid, } p \text {-hydroxybenzoic acid, caffeic acid, gallic acid, ferulic } \\
\text { acid, rutin, and resveratrol; RL increased the content of } \\
p \text {-hydroxybenzoic acid, caffeic acid, } p \text {-coumaric acid, ferulic acid, and } \\
\text { rutin; YL increased } p \text {-hydroxybenzoic acid, caffeic acid, gallic acid, } \\
\quad p \text {-coumaric acid, ferulic acid, rutin, and resveratrol. }\end{array}$ & [112] \\
\hline $\begin{array}{l}\text { Canola sprouts } \\
\text { (Brassica napus L.) }\end{array}$ & $\begin{array}{c}\text { WL }\left(380 \mathrm{~nm}, 50 \mu \mathrm{mol} \mathrm{m}{ }^{-2} \cdot \mathrm{s}^{-1}\right), \operatorname{BL}(470 \mathrm{~nm}, \\
\left.50 \mu \mathrm{mol} \mathrm{m}{ }^{-2} \cdot \mathrm{s}^{-1}\right), \operatorname{RL}\left(660 \mathrm{~nm}, 50 \mu \mathrm{mol} \mathrm{m}{ }^{-2} \cdot \mathrm{s}^{-1}\right) \\
\text { BL }+ \text { RL; } 16-\mathrm{h} \text { photoperiod }\end{array}$ & Sprouting & $\begin{array}{l}\text { BL was more effective than WL, BL + RL, and RL in increasing the } \\
\text { content of phenolic acids, flavonoids, and catechin. BL increased the } \\
\text { content of benzoic acid, (+)-catechin, caffeic acid, and (-)-epicatechin; } \\
\text { WL increased the contents of rutin. }\end{array}$ & [113] \\
\hline $\begin{array}{l}\text { Lettuce (Lactuca sativa L. } \\
\text { Cv. 'Grizzly' }\end{array}$ & $\begin{array}{l}\text { WL }\left(380-760 \mathrm{~nm}, 300 \mu \mathrm{mol} \mathrm{m}{ }^{-2} \cdot \mathrm{s}^{-1}\right), \mathrm{RL}(650-665 \mathrm{~nm} \\
\left.300 \mu \mathrm{mol} \mathrm{m}{ }^{-2} \cdot \mathrm{s}^{-1}\right), \mathrm{BL}\left(460-475 \mathrm{~nm}, 300 \mu \mathrm{mol} \mathrm{m}{ }^{-2} \cdot \mathrm{s}^{-1}\right) \\
\text { or RL + BL }(70 \%: 30 \%), 14-\mathrm{h} \text { photoperiod }\end{array}$ & Growth & $\mathrm{WL}>\mathrm{BL}$ increased the TPC & [96] \\
\hline $\begin{array}{l}\text { Sarcandra Herb } \\
\text { (Sarcandra glabra) }\end{array}$ & $\begin{array}{l}\text { WL }\left(380-760 \mathrm{~nm}, 80 \mu \mathrm{mol} \mathrm{m}{ }^{-2} \cdot \mathrm{s}^{-1}\right), \mathrm{RL}, 656 \mathrm{~nm} \text {, } \\
\left.\left.80 \mu \mathrm{mol} \mathrm{m}{ }^{-2} \cdot \mathrm{s}^{-1}\right), \mathrm{BL}, 450 \mathrm{~nm} 80 \mu \mathrm{mol} \mathrm{m}{ }^{-2} \cdot \mathrm{s}^{-1}\right) \\
\text { 16-h photoperiod }\end{array}$ & Growth & $\begin{array}{l}\text { BL increased the levels of cinnamic acid, } 4 \text {-coumaric acid, chalcone, } \\
\text { naringenin quercitin,kaempferol, and rutin, while it reduced the caffeic } \\
\text { acid content. BL increased the expression of of key enzymes involved in } \\
\text { the biosynthesis of phenolics (PAL, FLS) }\end{array}$ & [97] \\
\hline $\begin{array}{l}\text { Van'sweet cherry } \\
\text { (Prunus avium L.) }\end{array}$ & $\begin{array}{c}\text { UV-B }\left(310 \mathrm{~nm}, 0.046 \mathrm{~W} \mathrm{~m}^{-2}\right), \mathrm{BL}\left(444 \mathrm{~nm}, 1 \mathrm{~W} \mathrm{~m}^{-2}\right), \mathrm{WBG} \\
\text { composed by BL (470nm), GL (520 nm) and } \mathrm{WL} \text { with a } \\
\text { total } 3.6 \text { radiant flux } \mathrm{W} \mathrm{m}^{2}\end{array}$ & Postharvest & $\begin{array}{l}\text { BL increased the content of cyanidin 3-O-glucoside, cyanidin } \\
\text { 3-O-rutinoside; BL was more effective than WBG in increasing } \\
\text { PAL activity }\end{array}$ & [100] \\
\hline
\end{tabular}




\subsection{Photosynthetic Pigments}

Chlorophylls (chls), carotenoids, and anthocyanins represent the main class of plant pigments in nature $[114,115]$. Chls are magnesium-tetrapyrrole pigments and are the most abundant and ubiquitous photosynthetic pigments distributed in higher plants, algae, and cyanobacteria. They have been classified into five groups ( $\mathrm{chl} \mathrm{a,b}, \mathrm{c}, \mathrm{d}$, and $\mathrm{f}$ ) based on the variations in five-membered ring structures or side chains [116]. All green plants contain chl a and b, both located within the thylakoid membrane of chloroplasts, whereas $\mathrm{chl} \mathrm{c}, \mathrm{d}$, and the more recently identified chl $\mathrm{f}$ are present in algae and cyanobacteria. Chls biosynthesis and its regulation have been extensively investigated [117-120]. It is a complex pathway involving more than 17 enzymes and mainly subdivided into five parts: synthesis of 5-aminolevulinate acid (ALA), condensation of two ALA molecules to form a pyrrole ring (porphobilinogen, PBG), polymerization of four molecules of PBG to form a linear tetrapyrrole, conversion to the circular protoporphyrin IX (PPIX) via several decarboxylation and oxygenation reactions, and insertion of Mg to PPIX (more details in Figure S3).

Chls are green in color because they reflect the GL and absorb strongly in the red (625$675 \mathrm{~nm}$ ) and blue regions ( $425-475 \mathrm{~nm}$ ) of the visible spectrum. Chl a is the most abundant form which is present both in the reaction centers and in the light-harvesting complexes, whereas chlorophyll $\mathrm{b}$ is present in higher plants as a light-harvesting accessory pigment.

Carotenoids are lipophilic secondary metabolites, mainly belonging to the terpenoid group, and can be divided into two groups: carotenes, such as $\alpha$-carotene, $\beta$-carotene, $\gamma$-carotene, and lycopene, and xanthophylls, such as $\beta$-cryptoxanthin, lutein, zeaxanthin, and astaxanthin. They are pigments abundantly produced in floral tissues and fruits, providing them with the orange, red, and yellow colors. Carotenoids are components of the light-harvesting complex in chloroplasts and can limit the damage to cell membranes caused by excess light. They are primarily involved in photosynthesis and photoprotection, as they absorb light in the blue, green, and violet regions. The majority of carotenoids are bound to the photosynthetic apparatus: they collaborate with chlorophylls in promoting light uptake and quenching the excess energy which would otherwise lead to the formation of the oxidant singlet oxygen $\left({ }^{1} \mathrm{O}_{2}\right)$ [17]. Xanthophylls can also provide photoprotection by the so-called non-photochemical quenching (NPQ) in which violaxanthin, antheraxanthin, and lutein epoxide are converted to zeaxanthin and lutein. This reaction promotes energy dissipation in the light-harvesting antenna proteins through harmless heat when excess energy is harvested [121]. In non-photosynthetic organelles, they act as antioxidants, color attractants, and precursors of plant hormones.

Indeed, plant hormones strigolactone and abscisic acid are produced from the xanthophyll violaxanthin, thus implying the indirect involvement of carotenoids in plant growth and development [122].

Light regulation of carotenoids is essential to counterbalance ROS production and to maintain the redox status of the cell. In fact, chloroplasts are one of the sites where ROS are produced the most [123]. Carotenoids are important players of the chloroplast redox homeostasis, acting both as antioxidants and as signal molecules in their oxidized forms [124].

The accumulation of carotenoids and other pigments is genetically driven in many plants and fruits. However, light plays a very important role in their biosynthesis and accumulation, having a stimulating effect [125].

Light quality and intensity, as well as temperature, and storage conditions highly influence the photosynthetic process through the content of photosynthetic pigments, [126-128]. As reported for the phenolic compounds, also the chlorophyll and carotenoid biosynthesis can be regulated by light-responsive genes [129-131].

With regard to chls, previous studies have identified differentially expressed genes in plants that are regulated by GL, BL, and RL [132-134]. In particular, Li and colleagues [134] showed that the content of chl into the leaves of grape plantlets grown under BL was significantly higher compared to the content in plantlets grown under $\mathrm{WL}, \mathrm{GL}$, or RL. The 
authors highlighted that the photosynthetic pigment contents and chloroplast development in the leaves of grape plantlets were notably promoted by BL but were inhibited by GL or RL. The results obtained from the RNA-seq analysis revealed that BL up-regulated eight key genes involved in the chl biosynthesis, including glutamate-1-semialdehyde 2, 1-aminomutase (HemL), hydroxymethylbilane synthase (HemC), uroporphyrinogen decarboxylase (HemE), coproporphyrinogen III oxidase (HemF), protoporphyrinogen oxidase (HemY), magnesium-protoporphyrin-O-methyltransferase, protochlorophyllide reductase, and chlorophyll(ide) b reductase (more details in Figure S3).

LEDs have been exploited to increase carotenoids and xanthophylls, such as $\beta$ cryptoxanthin, antheraxanthin, violaxanthin, and lutein. Despite having an important role in photoprotection, the increase in such compounds has also a commercial significance in many foods, such as citrus fruits, because of their importance in determining the external and internal coloration, which is an important commercial feature $[135,136]$. The enzyme phytoene synthase (PSY) is the rate-limiting enzyme in the carotenoid biosynthetic pathway; the PSY encoding gene is under the direct regulation of PIFs, which are degraded or activated by light [137]. Moreover, other carotenoid genes can be up-regulated by RL, such as lycopene- $\beta$-cyclase (LCYB), $\beta$-carotene hydroxylase (CHYB), and violaxanthin de-epoxidase (VDE) (Figure S4) [98]. BL has been frequently reported to be able to induce the expression of PSY and the accumulation of beta carotene in mandarin (Citrus unshiu Marc.) [135], baikal skullcap (Scutellaria baicalensis) [138], and different microgreens [109]. In contrast, some other studies showed that RL was more efficient than BL in increasing the carotenoids or chl contents [96,139-141], even though exposure to RL notably affects chl contents by down-regulating the tetrapyrrole precursor ALA [142]

Overall, most of the studies listed in Table 4 showed that the use of mixtures such as $\mathrm{RL}+\mathrm{BL}[96,142-146]$ or fluorescent $\mathrm{WL}+\mathrm{RL}$ or BL $[147,148]$ has proven to be more efficient compared to monochromatic treatments. As regards GL and YL, very few studies report their use, with little or no significant results [56,139,142,149].

Limited data are available with regard to the effect of the irradiance levels on carotenoids accumulation. As reported for other antioxidants, the effects are not univocal and depend on the species, compound considered, and type of light [150]. Chl synthesis is notably affected by light intensity [151]. In a recent study, Loconsole and colleagues [152] highlighted that at the highest PPFD $\left(194.54 \mu \mathrm{mol} \mathrm{m}{ }^{-2} \cdot \mathrm{s}^{-1}\right)$, the content of chlorophyll and carotenoid was the lowest, while the opposite was observed for the lowest light intensity and shortest photoperiod. However, in a previous study, Samuoliené et al. [153] showed that increasing PPFD level led to an increase in the content of chlorophylls and carotenoids. 


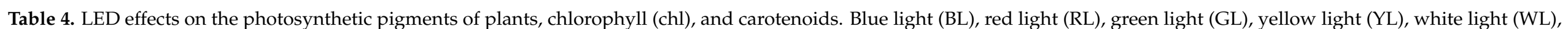

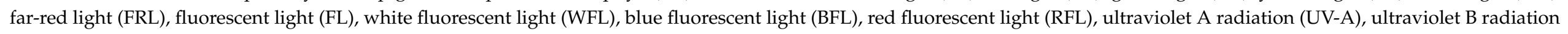
(UV-B), ultraviolet $C$ radiation (UV-C).

\begin{tabular}{|c|c|c|c|c|}
\hline Plant Species & $\begin{array}{c}\text { LED (Wavelength, Intensity), Photoperiod, and } \\
\text { Experimental Parameters }\end{array}$ & $\begin{array}{c}\text { Type of } \\
\text { Application }\end{array}$ & Effect & Reference \\
\hline $\begin{array}{c}\text { Chinese cabbage seeds (Brassica campestris } \\
\text { L. Teaiqing) }\end{array}$ & $\begin{array}{l}\text { YL }\left(590 \mathrm{~nm}, 150 \mu \mathrm{mol} \mathrm{m}{ }^{-2} \cdot \mathrm{s}^{-1}\right), \mathrm{GL}\left(520 \mathrm{~nm}, 150 \mu \mathrm{mol} \mathrm{m}-2 \cdot \mathrm{s}^{-1}\right) \\
\operatorname{RL}\left(658 \mathrm{~nm}, 150 \mu \mathrm{mol} \mathrm{m}{ }^{-2} \cdot \mathrm{s}^{-1}\right), \text { BL }\left(460 \mathrm{~nm}, 150 \mu \mathrm{mol} \mathrm{m}{ }^{-2} \cdot \mathrm{s}^{-1}\right) \\
\text { RL + BL }(6: 1 \mathrm{ratio}) ; 12 \text {-h photoperiod }\end{array}$ & Growth & $\begin{array}{l}\text { All LEDs except RL + BL led to a decrease } \\
\text { in total chl and carotenoids }\end{array}$ & [142] \\
\hline Lettuce (Lactuca sativa L. cv. 'Grizzly' & $\begin{array}{l}\text { WL }\left(380-760 \mathrm{~nm}, 300 \mu \mathrm{mol} \mathrm{m}{ }^{-2} \cdot \mathrm{s}^{-1}\right), \mathrm{RL}(650-665 \mathrm{~nm}, \\
\left.300 \mu \mathrm{mol} \mathrm{m}{ }^{-2} \cdot \mathrm{s}^{-1}\right), \mathrm{BL}\left(460-475 \mathrm{~nm}, 300 \mu \mathrm{mol} \mathrm{m}{ }^{-2} \cdot \mathrm{s}^{-1}\right) \\
\text { orRL + BL }(70 \%: 30 \%), 14-\mathrm{h} \text { photoperiod }\end{array}$ & Growth & $\begin{array}{l}\mathrm{RL}+\mathrm{BL}>\mathrm{RL}>\mathrm{BL} \text { increased the total chl; } \\
\mathrm{RL}+\mathrm{BL} \text { increased the total carotenoids. All } \\
\text { LEDs improved the photosynthetic rate }\end{array}$ & [96] \\
\hline Satsuma mandarin (Citrus unshiu Marc.) & $\begin{array}{c}\left.\mathrm{BL}\left(470 \mathrm{~nm}, 50 \mu \mathrm{mol} \mathrm{m}{ }^{-2} \cdot \mathrm{s}^{-1}\right), \mathrm{RL}(660 \mathrm{~nm}) 50 \mu \mathrm{mol} \mathrm{m}{ }^{-2} \cdot \mathrm{s}^{-1}\right) \\
\text { continuous irradiation for } 6 \text { days at } 20^{\circ} \mathrm{C}\end{array}$ & Postharvest & $\begin{array}{l}\text { BL increased the expression of carotenoid } \\
\text { biosynthetic genes and carotenoids content }\end{array}$ & [135] \\
\hline $\begin{array}{l}\text { Pak choi (Brassica rapa ssp. chinensis cv. } \\
\text { Black Behi) }\end{array}$ & $\begin{array}{c}\left.\text { BL (453nm, } 80 \mu \mathrm{mol} \mathrm{m}^{-2} \cdot \mathrm{s}^{-1}\right), \mathrm{RL}\left(633 \mathrm{~nm}, 80 \mu \mathrm{mol} \mathrm{m} \mathrm{m}^{-2} \cdot \mathrm{s}^{-1}\right), \mathrm{WL} \\
\left(404-789 \mathrm{~nm}, 80 \mu \mathrm{mol} \mathrm{m}^{-2} \cdot \mathrm{s}^{-1}\right) ; 12-\mathrm{h} \text { photoperiod }\end{array}$ & Growth & $\begin{array}{l}\text { WL }>\text { RL }>\text { BL increased the carotenoid and } \\
\text { chlorophyll contents }\end{array}$ & [140] \\
\hline Sweet oranges (Citrus sinensis (L.) Osbeck) & $\begin{array}{l}\text { RL }\left(660 \mathrm{~nm}, 150 \mu \mathrm{mol} \mathrm{m}^{-2} \cdot \mathrm{s}^{-1}\right), \text { BL }\left(470 \mathrm{~nm}, 200 \mu \mathrm{mol} \mathrm{m}-2 \cdot \mathrm{s}^{-1}\right) \\
\text { WL }\left(100 \mu \mathrm{mol} \mathrm{m}{ }^{-2} \cdot \mathrm{s}^{-1}\right), \mathrm{UVA}^{-}\left(315-400 \mathrm{~nm}, 100 \mu \mathrm{mol} \mathrm{m}{ }^{-2} \cdot \mathrm{s}^{-1}\right) \\
\text { UVB }\left(270-315 \mathrm{~nm}, 100 \mu \mathrm{mol} \mathrm{m}{ }^{-2} \cdot \mathrm{s}^{-1}\right) \text {, UVC }(100-280 \mathrm{~nm} \\
\left.100 \mu \mathrm{mol} \mathrm{m}{ }^{-2} \cdot \mathrm{s}^{-1}\right) ; \text { continuous irradiation for } 6 \text { days }\end{array}$ & Postharvest & Dark $>$ RL increased the carotenoid content & [154] \\
\hline $\begin{array}{l}\text { Mustard (Brassica juncea L., 'Red Lion'), } \\
\text { beet (Beta vulgaris L., 'Bulls Blood'), and } \\
\text { parsley (Petroselinum crispum Mill., 'Plain } \\
\text { Leaved or French) }\end{array}$ & $\begin{array}{c}\text { Different combinations of BL }\left(447 \mathrm{~nm}, 300 \mu \mathrm{mol} \mathrm{m}{ }^{-2} \cdot \mathrm{s}^{-1}\right) \mathrm{RL} \\
\left(638 \mathrm{~nm}, 300 \mu \mathrm{mol} \mathrm{m}{ }^{-2} \cdot \mathrm{s}^{-1}\right) \text {, FRL }\left(731 \mathrm{~nm}, 300 \mu \mathrm{mol} \mathrm{m}^{-2} \cdot \mathrm{s}^{-1}\right) \\
\text { 16-h photoperiod }\end{array}$ & Growth & $\begin{array}{l}\text { BL led to the accumulation of chlorophylls, } \\
\text { carotenoids, carotenes, lutein, violaxanthin, } \\
\text { and zeathin }\end{array}$ & [109] \\
\hline Broccoli (Brassica oleracea L. var. italica) & 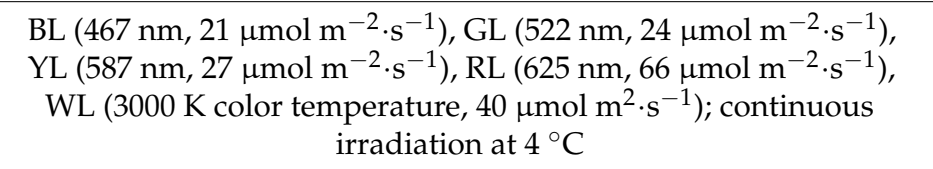 & Postharvest & $\begin{array}{l}\text { GL increased the chlorophyll content; no } \\
\text { effect on carotenoids elicited by all LEDs }\end{array}$ & [56] \\
\hline $\begin{array}{l}\text { Green Oak Leaf lettuce } \\
\text { (Lactuca sativa var. crispa) }\end{array}$ & $\begin{array}{l}\text { WFL }\left(400-700 \mathrm{~nm}, 133 \mu \mathrm{mol} \mathrm{m}^{-2} \cdot \mathrm{s}^{-1}\right), \mathrm{BL}(460 \mathrm{~nm}, \\
\left.133 \mu \mathrm{mol} \mathrm{m}{ }^{-2} \cdot \mathrm{s}^{-1}\right), \mathrm{RL}\left(630 \mathrm{~nm}, 133 \mu \mathrm{mol} \mathrm{m}{ }^{-2} \cdot \mathrm{s}^{-1}\right), \mathrm{FBL} \\
(\mathrm{WFL}+\mathrm{BL}), \text { FRL }(\mathrm{WFL}+\mathrm{RL}) ; 14-\mathrm{h} \text { photoperiod }\end{array}$ & Growth & $\begin{aligned} \text { FLR }>\text { FLB }>\text { RB increased total chlorophyll } \\
\\
\text { content and total carotenoids }\end{aligned}$ & [147] \\
\hline
\end{tabular}


Table 4. Cont.

\begin{tabular}{|c|c|c|c|c|}
\hline Plant Species & $\begin{array}{l}\text { LED (Wavelength, Intensity), Photoperiod, and } \\
\text { Experimental Parameters }\end{array}$ & $\begin{array}{c}\text { Type of } \\
\text { Application }\end{array}$ & Effect & Reference \\
\hline $\begin{array}{l}\text { Green Oak Leaf lettuce } \\
\text { (Lactuca sativa var. crispa) }\end{array}$ & $\begin{array}{l}\text { WFL + FRL }\left(850 \mathrm{~nm}, 135 \mu \mathrm{mol} \mathrm{m}{ }^{-2} \cdot \mathrm{s}^{-1}\right), \mathrm{WFL}+\mathrm{RL}(660 \mathrm{~nm}, \\
\left.135 \mu \mathrm{mol} \mathrm{m}{ }^{-2} \cdot \mathrm{s}^{-1}\right), W F L+\mathrm{YL}\left(596 \mathrm{~nm}, 135 \mu \mathrm{mol} \mathrm{m}{ }^{-2} \cdot \mathrm{s}^{-1}\right) \\
\text { WFL + GL }\left(522 \mathrm{~nm}, 135 \mu \mathrm{mol} \mathrm{m}{ }^{-2} \cdot \mathrm{s}^{-1}\right), W F L+B L(450 \mathrm{~nm}, \\
\left.135 \mu \mathrm{mol} \mathrm{m}{ }^{-2} \cdot \mathrm{s}^{-1}\right)\end{array}$ & Growth & $\begin{array}{l}\text { WFL + RL and WFL + BL increased the } \\
\text { total chlorophyll and carotenoid content }\end{array}$ & [148] \\
\hline Baikal skullcap (Scutellaria baicalensis) & $\begin{array}{c}\mathrm{RL}\left(660 \mathrm{~nm}, 50 \mu \mathrm{mol} \mathrm{m}{ }^{-2} \cdot \mathrm{s}^{-1}\right), \mathrm{BL}\left(470 \mathrm{~nm}, 50 \mu \mathrm{mol} \mathrm{m}{ }^{-2} \cdot \mathrm{s}^{-1}\right) \\
\text { WL }\left(380 \mathrm{~nm}, 50 \mu \mathrm{mol} \mathrm{m}{ }^{-2} \cdot \mathrm{s}^{-1}\right) ; 16-\mathrm{h} \text { photoperiod }\end{array}$ & Growth & $\begin{array}{l}\mathrm{BL}>\mathrm{RL}>\mathrm{WL} \text { increased the expression of } \\
\text { carotenoids photosynthetic genes; BL } \\
\text { increased the zeaxanthin, } \beta \text {-carotene, and } \\
\text { 9-cis- } \beta \text {-carotene content }\end{array}$ & [138] \\
\hline Green Chili (Capsicum annuum L.) & $\begin{array}{c}\mathrm{RL}\left(660 \mathrm{~nm}, 50 \mu \mathrm{mol} \mathrm{m}{ }^{-2} \cdot \mathrm{s}^{-1}\right), \mathrm{BL}\left(470 \mathrm{~nm}, 50 \mu \mathrm{mol} \mathrm{m}{ }^{-2} \cdot \mathrm{s}^{-1}\right) \\
\text { continuous irradiation for } 3 \text { days }\end{array}$ & Postharvest & $\begin{array}{c}\text { RL induced the expression of } \\
\text { lycopene- } \beta \text {-cyclase (Lcyb), } \beta \text {-carotene } \\
\text { hydroxylase (CrtZ), and } \\
\text { capsanthin/capsolubin synthase (Ccs); BL } \\
\text { induced the expression of PS; RL > BL } \\
\text { increased the carotene, free-capsanthin, and } \\
\text { total carotenoid contents }\end{array}$ & [141] \\
\hline
\end{tabular}




\subsection{Glucosinolates}

Glucosinolates (GLSs) are bioactive nitrogen- and sulfur-containing compounds occurring in some dicotyledonous angiosperms of the order Capparales, especially in the economically important Brassicaceae family $[155,156]$. Over 120 GLSs have been identified with a common $\beta$-D-thioglucosides $\mathrm{N}$-hydroximinosulfates core structure and a variable side chain derived from amino acids [157]. They have been classified into three groups based on the structure of different amino acids precursors: aliphatic GLSs derived from alanine, leucine, isoleucine, methionine, or valine, aromatic GLSs derived from phenylalanine or tyrosine, and indole GLSs derived from tryptophan [156].

The pungent taste of the edible plants containing GLSs is mainly due to the presence of hydrolysis products of GLSs, including isothiocyanates, nitriles, oxazolidine-2-thiones, epithionitriles, and thiocyanates, formed when plants are stressed by biotic and abiotic factors. The degradation process begins with the hydrolysis of the thioglucoside linkage, catalyzed by the enzyme myrosinase, into glucose, sulfate, and an unstable aglycone, which then rearranges spontaneously into a wide range of active compounds depending on the structure of the side chain and the reaction conditions [149].

Several studies have shown that the GLSs hydrolysis products represent the bioactive component of these compounds. They are well-known for their involvement in plant defense response against insects and pathogens [158-160]. Moreover, several GLSs hydrolysis products may play a prominent role in chronic diseases prevention, including certain types of cancer, diabetes, cardiovascular disease, neurodegeneration, and several inflammatory disorders due to the oxidative stress [161-164]. The antioxidant properties of GLSs hydrolysis products were largely investigated. In particular, in vitro and in vivo studies have shown the ability of some GLSs hydrolysis products, generally associated with aliphatic isothiocyanate, to prevent cancer development through the induction of some detoxification enzymes (Phase II), including NAD(P)H quinone reductase, heme oxygenase 1 , and glutathione $S$ transferases [165].

GLSs, together with the phytochemicals mentioned above, have been reported to be affected by light of different wavelengths, and there is evidence that the effect of light to plant biomass production can influence the secondary metabolism in relation to GLS biosynthesis [2,166]. Various LEDs have been tested for their ability to influence GLSs contents, showing that their effects strongly depend on plant species and cultivar, plant organs, and GLS genotype [113,167-169].

Although the genetic bases of GSL biosynthesis were well investigated, little is known about the effect of different LED lights on the genes involved in GLS biosynthesis and its regulation. Some studies conducted on Arabidopsis and some other Brassica species revealed that GS-ELONG, GS-OX, GS-AOP, and GS-OH loci play an important role in GLS biosynthesis and content variability [170-172]. In 2001, Kliebenstein and colleagues [173] showed that the AOP2 (GSL-ALK locus) and AOP3 (GSL-OHP locus) genes, which map to the GSL-AOP locus, are responsible for converting methylsulfinyl alkyl glucosinolates into alkenyl and hydroxyalkyl glucosinolates, respectively. The presence or absence of either of the loci, as well as the functional or nonfunctional copy of those two genes, influences the type of glucosinolate produced in a defined species. Furthermore, in Arabidopsis, the expression of the $A O P 2$ gene was found to be up-regulated by light and highly expressed in the photosynthetic parts of the plant [174] (Figure S5). A recent study evaluated the effect of dark, white, red, and blue LEDs on the health-promoting phytochemicals and antioxidant capacity of Chinese kale sprouts [168]. The results showed that blue light, unlike the other light treatments, significantly decreased the content of gluconapin in shoots, while it increased the glucoraphanin content in roots. In aliphatic GLS biosynthesis, AOP2 catalyzes the conversion of glucoraphanin to gluconapin [172]. This might indicate that BL negatively affects the AOP2 activity, though further research is needed for a better understanding of the mechanism involved. 
The most pronounced effect on the GLSs contents by LED lighting treatment is achieved by BL and RL, though few studies analyzed the impact of more LED wavebands on GLSs-containing plants [111,175].

When looking further at the individual experiments, effects varied across the analyzed species and tissues. For example, Kopsell and Sams [176] analyzed the concentrations of GLSs in broccoli microgreen tissues after exposure to RL/BL and BL treatments and found that the level of many aliphatic GLSs increased after exposure to the BL treatment, while indole GLSs were unaffected by the LED lighting treatment. Similarly, the level of aliphatic GSLs increased and that of indole GLSs was lower when plants of Cardamine fauriei were grown under BL irradiation [177]. However, in other studies, the BL treatment showed the opposite effect or no effect in GLSs biosynthesis [168,169,178,179].. Qian and colleagues [168] showed a significant reduction in aliphatic and indole GLSs contents in the shoots of Chinese kale sprouts, after exposure to BL treatment. Further, neither high blue ratio (31.7\% $\mathrm{BL} / 66.3 \% \mathrm{RL})$ nor low blue ratio $(14.8 \% \mathrm{BL} / 81.3 \% \mathrm{RL})$ seemed to affect the GLSs content on different cultivars of rapeseed sprouts [169]. As suggested by some authors [2,176], light treatment might affect the side chain of the GLS rather than the core structure, and BL likely positively affects the amino acid involved in the aliphatic and aromatic GLSs biosynthesis, whereas it may have no effect on indole GLS (tryptophanderived) biosynthesis. This hypothesis should be further investigated to reveal the exact mechanism of LED light on GLSs synthesis. The most recent studies on LED effects on GLS content in different plants are summarized in Table 5.

\section{LED Lighting: Advantages and Challenges in Plant Growth and Postharvest Management}

LED technology has grown tremendously on a global scale over the last decade, quickly replacing traditional lighting systems (incandescent, fluorescent, high-intensity discharge lamps, HID) in different fields, including the horticultural sector, as supported by a growing research community [21,180]. Furthermore, the strategic collaboration among LED manufacturers, plant producers, and academics is enabling extraordinary advances in the science and application of plant lighting, ranging from growth chambers to greenhouse application, vertical farming, and postharvest yield/crop management.

As mentioned above, higher energy efficiency, versatility, long lifetime, and cost saving features are some of the major advantages of LED lighting. Unlike HID and HPS, LEDs show reduced heat emission leading to prevent thermal degradation and optimizing space in indoor farming and storage management applications. Moreover, LED technology, compared to conventional lamps, enables a wide variety of spectral outputs and allows for controlling the directionality of light and regulating light intensity, all of which make it more suitable for the growth, preservation, and storage of fresh horticultural products [180-182].

In this review, we have focused on LEDs' effects on some plant metabolites, with particular attention on the content of some antioxidant compounds both during the plant growth and at the postharvest level. Furthermore, specific light wavelengths and intensities may also affect the content of potentially harmful or undesirable molecules, reducing or improving the nutritional value of plants $[55,183]$. LED technology offers several advantages with respect to the conventional lighting systems; however, several challenges still have to be tackled, as reported in Figure 5. 


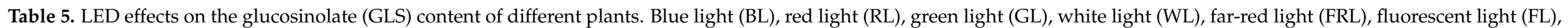
white fluorescent light (WFL), high blue ratio (HB), low blue ratio (LB).

\begin{tabular}{|c|c|c|c|c|}
\hline Plant Species & LED (Wavelength, Intensity), Photoperiod, and Experimental Parameters & $\begin{array}{c}\text { Type of } \\
\text { Application }\end{array}$ & Effect & Reference \\
\hline $\begin{array}{l}\text { Broccoli (Brassica oleracea L. var. italica cv. } \\
\text { Chaoda No. 1) }\end{array}$ & $\begin{array}{c}\text { WFL (300-700 nm, }\left(12-13(\mu \mathrm{mol} \mathrm{m})^{-2} \cdot \mathrm{s}^{-1}\right) \mathrm{GL}\left(520 \mathrm{~nm}, 12-13 \mu \mathrm{mol} \mathrm{m}{ }^{-2} \cdot \mathrm{s}^{-1}\right) \\
\text { 12-h photoperiod }\end{array}$ & Postharvest & GL increased GLSs contents & [108] \\
\hline Sprouting Canola (Brassica napus L.) & $\begin{array}{c}\mathrm{WL}\left(380 \mathrm{~nm}, 50 \mu \mathrm{mol} \mathrm{m}{ }^{-2} \cdot \mathrm{s}^{-1}\right) \mathrm{BL}\left(470 \mathrm{~nm}, 50 \mu \mathrm{mol} \mathrm{m}^{-2} \cdot \mathrm{s}^{-1}\right) \mathrm{RL}(660 \mathrm{~nm} \text {, } \\
\left.50 \mu \mathrm{mol} \mathrm{m}{ }^{-2} \cdot \mathrm{s}^{-1}\right) \text { BL + RL; 16-h photoperiod }\end{array}$ & Growth & $\begin{array}{l}\text { BL + RL determined the lowest levels of total GLSs. RL } \\
\text { increased the level of sinigrin, glucobrassicin, and } \\
\text { 4-methoxy glucobrassicin, while BL increased the level } \\
\text { of glucoraphanin. WL and BL increased the level of } \\
\text { glucoalyssin and gluconapin }\end{array}$ & [113] \\
\hline $\begin{array}{l}\text { kale sprouts (Brassica oleacea var. } \\
\text { alboglabra Bailey) }\end{array}$ & $\begin{array}{l}\left.\text { WL (440-660 nm, } 30 \mu \mathrm{mol} \mathrm{m}^{-2} \cdot \mathrm{s}^{-1}\right) \text { RL }\left(660 \mathrm{~nm}, 30 \mu \mathrm{mol} \mathrm{m}{ }^{-2} \cdot \mathrm{s}^{-1}\right) \mathrm{BL} \\
\left(470 \mathrm{~nm}, 30 \mu \mathrm{mol} \mathrm{m}^{-2} \cdot \mathrm{s}^{-1}\right) \cdot 16-\mathrm{h} \text { photoperiod }\end{array}$ & Growth & $\begin{array}{l}\text { No effects elicited by WL and RL; BL inhibited the } \\
\text { accumulation of GLSs in shoots. }\end{array}$ & [168] \\
\hline $\begin{array}{l}\text { white- and yellow-flowering rapeseed } \\
\text { (Brassica napus L.) }\end{array}$ & $\begin{array}{c}\left.\text { HB (31.7\% blue/ } 66.3 \% \text { red, } 121 \pm 7 \mu \mathrm{mol} \mathrm{m}^{-2} \cdot \mathrm{s}^{-1}\right) \mathrm{LB}(14.8 \% \text { blue } / 81.3 \% \text { red, } \\
\left.121 \pm 7 \mu \mathrm{mol} \mathrm{m}{ }^{-2} \cdot \mathrm{s}^{-1}\right) 14-\mathrm{h} \text { photoperiod }\end{array}$ & Growth & $\begin{array}{l}\text { HB light decreased the contents of progoitrin. BL/RL } \\
\text { light ratios slightly affect GLSs content. }\end{array}$ & [169] \\
\hline Broccoli (Brassica oleracea var. italica) & $\begin{array}{c}\text { (A) FL (B) BL/RL (5\% } 447 \mathrm{~nm} / 95 \% 627 \mathrm{~nm})(\mathrm{C}) \mathrm{BL} / \mathrm{RL} / \mathrm{GL}(5 \% / 85 \% / 10 \% \\
530 \mathrm{~nm})(\mathrm{D}) \mathrm{BL} / \mathrm{RL}(20 \% / 80 \%)(\mathrm{E}) \mathrm{BL} / \mathrm{RL} / \mathrm{GL}(20 \% / 70 \% / 10 \%) \\
250 \mu \mathrm{mol} \mathrm{m}{ }^{-2} \cdot \mathrm{s}^{-1} ; 16-\mathrm{h} \text { photoperiod }\end{array}$ & Growth & $\begin{array}{c}\mathrm{D}>\mathrm{C}>\mathrm{B}>\mathrm{E}>\mathrm{A} \text { increased the level of aliphatic, } \\
\text { indoles, and total GLS. }\end{array}$ & [175] \\
\hline Broccoli (Brassica oleracea var. italica) & $\begin{array}{c}\mathrm{BL}+\mathrm{RL}\left(12 \% 470 \mathrm{~nm} / 88 \% 627 \mathrm{~nm} ; 350 \mu \mathrm{mol} \mathrm{m}{ }^{-2} \cdot \mathrm{s}^{-1}\right) ; \mathrm{BL}(470 \mathrm{~nm} ; \\
\left.41 \pm 2 \mu \mathrm{mol} \mathrm{m}{ }^{-2} \cdot \mathrm{s}^{-1}\right) \cdot 24-\mathrm{h} \text { photoperiod }\end{array}$ & Growth & $\begin{array}{l}\text { BL increased the level of glucoraphenin, epiprogoitrin, } \\
\text { and aliphatic GLSs, while indole GLSs were not } \\
\text { impacted by the LED lighting treatment. }\end{array}$ & [176] \\
\hline $\begin{array}{l}\text { Choy sum (Brassica rapa subsp. chinensis } \\
\text { var. parachinensis) }\end{array}$ & $\begin{array}{c}\text { RB: } 160 \mu \mathrm{mol} \mathrm{m}^{-2} \cdot \mathrm{s}^{-1} \text { and } 80 \mu \mathrm{mol} \mathrm{m}{ }^{-2} \cdot \mathrm{s}^{-1} ; \mathrm{WL}: 160 \mathrm{~W} \text { and } 80 \mathrm{~W} \text {; BL } \\
(450 \mathrm{~nm}) \mathrm{RL}(660 \mathrm{~nm}) \cdot 12-\mathrm{h} \text { photoperiod }\end{array}$ & Growth & $\begin{array}{l}\text { No significant difference in the total GSL content was } \\
\text { observed in response to the various LED light } \\
\text { treatments within the same growth stage. The changes } \\
\text { were more pronounced across growth stages. }\end{array}$ & [178] \\
\hline (Brassica napus L. ssp. rapifera Metzg) & $\begin{array}{c}\mathrm{RL}(660 \mathrm{~nm}), \mathrm{FR}(740 \mathrm{~nm}), \mathrm{RL} / \mathrm{FRL}(1: 1), \mathrm{BL}(460 \mathrm{~nm}) \\
\text { 24-h photoperiod;10 } \mu \mathrm{mol} \mathrm{m}{ }^{-2} \cdot \mathrm{s}^{-1} \text {. These treatments were given in } \\
\text { combination with temperature regimes of either constant } 15^{\circ} \mathrm{C}(100 \text { day }) \text { or } \\
15^{\circ} \mathrm{C}\left(65 \text { day) followed by } 9^{\circ} \mathrm{C}(66-100 \text { day })\right.\end{array}$ & Growth & $\begin{array}{l}\text { Total GLS concentrations were not different among } \\
\text { treatments, progoitrin was present in highest } \\
\text { concentration under LEDs containing far-red light, and } \\
\text { in lower concentration at } 9^{\circ} \mathrm{C} \text { compared to } 15^{\circ} \mathrm{C}\end{array}$ & [179] \\
\hline
\end{tabular}




\section{Advantages}

- Higher efficiency (37 - 120 lumens/Watt)

- Small heat dissipation.

- Specific emission range

- Uniform illumination

- Longer lifespan

- Greater robustness and safety

- Small size, very quick on/off time and easy to dim

\section{Challenges}

- Higher initial price

- Temperature dependence

- Voltage sensitivity

- Color rendering index is highly dependent on the particular color

Figure 5. Advantages and challenges of LEDs.

Although several studies have addressed the benefits of LEDs for the growth of horticultural crops and the enhancement of their nutritional value, the findings about their effect on the quantity and quality of the plant crops in the postharvest stage are relatively recent and focused on few fruits and vegetables species [182,184]. There is evidence that LED lighting can influence the shelf life and quality of fresh produce, inhibiting weight loss, senescence, and over-ripening, and enhancing the production of antioxidant compounds $[55,56,73,98,108,135]$. Most of the results showed that BL promotes the accumulation of phytochemical constituents, including polyphenol in bananas (Musa acuminate) [100], Vit $C$ in citrus juices (Citrus unshiu and Citrus sinensis) [72], Chinese cabbage (Brassica campestris) [75], and strawberry (Fragaria ananassa) [75], and anthocyanin in sweet cherries (Prunus avium) [84] and in Chinese bayberry fruit (Myrica rubra) [185]. In other studies, BL shows less effective results, compared to other light treatments. For instance, Song and colleagues [73] showed that RL was able to inhibit senescence of Pakchoi (Brassica rapa ssp. Chinensis) and to improve the content of chl, Vit C, and total soluble proteins, compared to BL and FR light. Similarly, Loi and colleagues [56] compared five light treatments during postharvest storage of broccoli (Brassica oleracea L. var. italica) (see Table 4) and revealed that chlorophyll content and TPC were higher under GL and RL treatments, respectively, while BL had no positive effects on Vit C levels.

Currently, RL and BL have been recognized as the most suitable treatments for plant growth and development of tailored food. However, there is a growing consensus that other LEDs, including YL or GL, may contribute, both monochromatically and combined, to promote higher biomass and yield or preserve plant quality [175,186,187]. In a recent review, Smith et al. [187] proved that supplemental GL to the LED light recipes may improve or maintain plant quality, yield, and water-use efficiency and contribute to photosynthetic carbon assimilation. They showed that unlike BL and RL, which are absorbed in the top and middle layers of leaf cells, respectively, GL is weakly absorbed by chlorophylls, and hence it can penetrate deeper and reach the bottom layer of cells owing to the phenomenon known as the detour effect [188]. However, the authors highlighted that not all green wavelengths have the same responses within the plant. For example, lettuce irradiated with different GL (peak wavelength at $510 \mathrm{~nm}, 520 \mathrm{~nm}$, and $530 \mathrm{~nm}$ ) and PPFD (100, 200, and $300 \mu \mathrm{mol} \mathrm{m}{ }^{-2} \cdot \mathrm{s}^{-1}$ ) showed distinct growth responses, even though the difference in peak wavelength among the GL was only $10 \mathrm{~nm}$ [189]. In particular, leaf elongation was stimulated more by GL at $530 \mathrm{~nm}$, while GL at $510 \mathrm{~nm}$ and higher intensity promoted 
plant growth. This result, and some other evidence in the literature over the years, showed that, even with outstanding advancements in LED technology in the horticultural field, further improvements are needed, not only in lamp performance metrics, but also in experimental design.

Until recently, the insufficient availability of data on lamp performance metrics and quality standards did not help growers to compare results and LED options, driving confusion and lack of references. In 2017, the American Society of Agricultural and Biological Engineers (ASABE) published the S640 standards on the quantities and units used to describe horticulture lighting (ASABE, 2017) [190], including 33 new metric definitions for horticultural lighting, among which are photosynthetic active radiation (PAR), expressed as photosynthetic photon flux (PPF, PAR emitted by a source, measured in units of micromoles) and photosynthetic photon flux density (PPFD, PAR that falls on a unit of surface area). Although these new metrics are compatible with metrics previously defined, they are, however, specific to the needs of horticulture and plant biology. Furthermore, for the evidence that, outside the visible light $(400-700 \mathrm{~nm})$, plants respond to UV and FR radiation, the metrics are divided into three spectral ranges: photosynthetic (400-700nm), UV (100-400nm), and far-red (700-800). Moreover, the document allows describing radiation in terms of quantity of energy (measured in watts) or photons (measured in micromoles). Afterwards, in 2018, ASABE released the S642 standard, focusing on the performance of LEDs, arrays, and modules relative to the impact on plant growth and development (ASABE, 2018) [191]. Lighting manufacturers are adopting the metrics used in the horticulture sector. However, a recent review [192] showed that 30\% of the LED lighting system producers included in the study still do not report the photosynthetic photon efficacy of lamps.

Besides the appropriate LED metrics implementation to the horticultural sector, there are some other challenges that need to be tackled, depending on the aim of the request (growth, postharvest, development). Among these, there are the influence of light intensity, irradiance, temperature, and power supply on the physiological and biochemical responses of the plant, and how those responses vary among species and within cultivars of the same species.

The monochromaticity property of LEDs limits the propagation of radiant heat, making them even more suitable for the horticultural sector, since they can avoid the harmful effects of radiant heat on the quality of agricultural commodities. Although LEDs are relatively efficient, about $65-70 \%$ of the supplied electric power generates heat instead of light because of low IQE and light extraction efficiency [193]. One of the major factors in determining the lumen output of an LED is the p-n junction temperature. As the temperature increases, the light intensity and LEDs lifetime decrease, and colorimetric properties are altered. The junction temperature is mainly influenced by three factors: environmental temperature, thermal resistance (defined as the rise in temperature of a component per unit of power dissipated) between the LED junction and its surrounding, and the driven current. For this reason, LED lamps generally require a proper cooling device and temperaturecontrolled environments [194] and this supports their use in refrigerators and in cold-chain storage or in transport vehicles.

A growing number of studies suggest that the overall quality of vegetables prior to or even after harvest is highly dependent not only on the spectral composition but also on LED intensity and photoperiod [195-197]. Jones-Baumgardt et al. [196] tested the effect of combined BL/RL (15:8 ratio) at six PPFD treatments on growth, yield, and quality of kale (Brassica napus L. 'Red Russian'), cabbage (Brassica oleracea L.), arugula (Eruca sativa L.), and mustard (Brassica juncea L. 'Ruby Streaks'), demonstrating that arugula and mustard exhibited greater levels of phenotypic plasticity to light intensity $\left(600 \mu \mathrm{mol} \mathrm{m}{ }^{-2} \cdot \mathrm{s}^{-1}\right)$ than kale and cabbage. Furthermore, low intensity seemed to improve the postharvest quality of fruits and prevent senescence during storage [198]. Light distribution and irradiance uniformity are also important parameters to be evaluated because the photosynthetic properties depend on the leaf age and/or distance between the lighting device and plant canopy; therefore, a different response might be revealed in the lower canopy compared to 
the upper leaves [181,199]. Moreover, since the intensity of light radiation that reaches a surface is inversely proportional to the square of the surface's distance from the source, light levels vary and are inconsistent as plants grow, which suggests that light output could be modified according to the plant photosynthetic requirements.

Overall, understanding the physiological responses induced by LED lights is a crucial step to regulate plant morphogenesis, enhance the nutritive value of crops, and preserve quality in postharvest fresh products. However, data from the literature are often contradictory because, over the years, many research projects focused their efforts on a few selected species or cultivars, and little is known about the comparison among closed species, more cultivars, or types of the same cultivar [22,169,200,201]. Eventually, further efforts should be devoted to including harmonized LED metrics and to comparing different light qualities and intensities in the same experimental design.

\section{LEDs as a Tool to Improve Microbiological Food Safety}

Food safety in the food chain is the basis for an effective functioning of national and international markets with trust and transparency. Food safety risks occur along the food chain due to different biological and chemical contaminants, and the development of novel methods for decontamination of food and food processing remains a major global problem that causes significant social, as well as economic, efforts.

The thermal techniques are the most efficient and used methods to eliminate pathogens, but their application cannot be applied to certain types of foods, such as fresh produce in ready-to-eat salads and so on.

Light is crucial for many organisms and can be influential for many cellular processes, being important for survival, growth, and reproduction [202].

Light induces cell damage, injury, and death in microorganisms through several mechanisms, which are related to the presence of photosensitive endogenous compounds such as porphyrins and flavins. The absorption of the light at specific wavelengths by these molecules promotes them to excited energy states [203] that can induce photodynamic reactions and locally generate ROS. The formed ROS then react with multiple cellular components, further causing microbial cell death by oxidative damage [204]. Experiments on various bacteria show that $\mathrm{BL}$ or near-UV radiation has been found to be most effective in inactivating cells, while RL has minimal efficacy. In particular, LEDs within the band of 400 to $450 \mathrm{~nm}$, with a peak wavelength of $405 \mathrm{~nm}$, are most effective, as the peak coincides with the absorption maximum of porphyrins [205-207]. The susceptibility of bacteria to the light appears to vary widely among species and depending on the exposure time.

Molecules with either antioxidant or ROS-generating functions are particularly interesting to investigate as these could provide an indication to explain the differences in inactivation rates among the different or the same species of bacteria. Kumar et al. [208] hypothesized that a host of other factors such as other inactivation pathways and microbial responses to light treatment may play critical roles in determining the extent of inactivation for a particular species.

In fungi, light is one of the most important signals, since it influences several physiological responses such as secondary metabolism, pigmentation, sexual development, asexual conidiation, and the circadian clock. The sensing of light in fungi is over a broad spectrum range, from UV to FR light. A variety of photoreceptors are conserved in fungi and the range of perceptible light intensities covers more than ten orders of magnitude [202]. The first knowledge about the influence of light on the growth and physiology of fungi was obtained on Neurospora crassa that has become the most prominent model system for studying mechanisms of photoreception, circadian rhythms. Moreover, in N. crassa light perception and the response to BL incubation $[209,210]$ have been elucidated at the molecular level. The white-collar complex is the first and best studied photoreceptor system in fungi. However, the increasing number of fungal genome sequences revealed the presence of a number of different photoreceptors in each fungus and suggests fascinating but rather complex and diverse regulatory systems. 
The effect of LED light has been studied to prevent fungal infection of fruits in postharvest storage. In general, BL at a moderate intensity was able, depending on fungal species, to dramatically reduce the soft rot area, mycelial growth, and sporulation of various fungi (Penicillium digitatum, P. italicum, and Phomopsis citri), on the surface of fruits compared with WL and darkness [211-214]. Additionally, in citrus fruit, BL was able to induce changes in ethylene production and phenolic compounds that are important players in the defense of citrus fruit against P. digitatum [215-219]. However, the molecular mechanism of $P$. digitatum resistance remains unknown [220].

$\mathrm{Yu}$ and Lee [221] studied an interesting application of RL (645 nm) that may be useful in overcoming limitations that LED irradiation possesses. The application of RL (645 $\mathrm{nm}$ ) on the surface of the fruit was more effective in enhancing the antifungal effect of Bacillus amyloliquefaciens by enhancing the motility and biofilm formation at $240 \mu \mathrm{mol} \mathrm{m}^{-2} \mathrm{~s}^{-1}$ compared with other wavelengths. The cell-free supernatant of bacteria irradiated with RL revealed a higher production of iturin and fengycin, which are antifungal lipopeptides. This synergistic application of antagonistic bacteria and LED irradiation by stimulating the growth of antagonistic biofilms might prevent fungal growth on fruits after LED irradiation is stopped. In fact, it is reported that LEDs do not reach the inner tissues of the plant; thus, they are not able to completely inhibit fungal growth [211].

Fungi are potent producers of secondary metabolites, such as antibiotics or mycotoxins [222,223], and light also controls the production of those metabolites. In particular, mycotoxins produced by toxigenic fungi represent a great concern worldwide either for the economic implications or for the health of the consumers. Light modulates mycotoxin production with a promoting or an inhibiting effect depending on the species and could be a new physical parameter to control and degrade the production of these metabolites, at least for surface-growing fungi. Some toxigenic fungi such as the Fusaria or Alternaria genera seem to be resistant to various light wavelengths. However, the production of secondary metabolites (e.g., mycotoxins) was reduced after the application of BL [224,225]. In fact, BL was the most effective in reducing ochratoxin biosynthesis, with results depending on the species treated. A clear correlation exists between the intensity of BL and the inhibitory effect. Weak royal BL led to a moderate reduction in ochratoxin A for Penicillium verrucosum, P. nordicum, Aspergillus steynii, and A. carbonarius. Higher intensities of royal BL were shown to reduce ochratoxin A biosynthesis to either non-detectable ( $P$. verrucosum, A. steynii) or to very low levels (A. carbonarius, P. nordicum) [224].

Light could represent a new resource against mycotoxin contamination, which can be developed in a targeted way, with limited costs and easily integrated in food processing and preservation.

\section{Perspectives}

LED technology provides unique advantages over the conventional lighting systems and proves to be extremely versatile. LEDs have the potential to regulate several aspects of plant growth, development, the accumulation of different secondary metabolites (Figure 6) [182], and the overall plant metabolome [226].

The positive effect on the antioxidant compounds of vegetables has several implications, which go beyond the simple nutraceutical value of the food. An increased antioxidant capability endows the plants with a higher resistance towards harsh environmental conditions (excessive light, drought, extreme temperatures), toxic pollutants, and pathogens [107,227]. Indeed, many secondary metabolites have been shown to possess antimicrobial and antifungal properties [228]. Light-induced resistance may also arise from the induction of defense genes and the salicylic acid pathway-mediated systemic acquired resistance [229]. This may potentially lead to a reduced need for chemical treatments in the field [230]. In addition, the use of LEDs in the postharvest can prolong the shelf life, delay senescence $[55,111]$, and, thus, reduce food waste. 


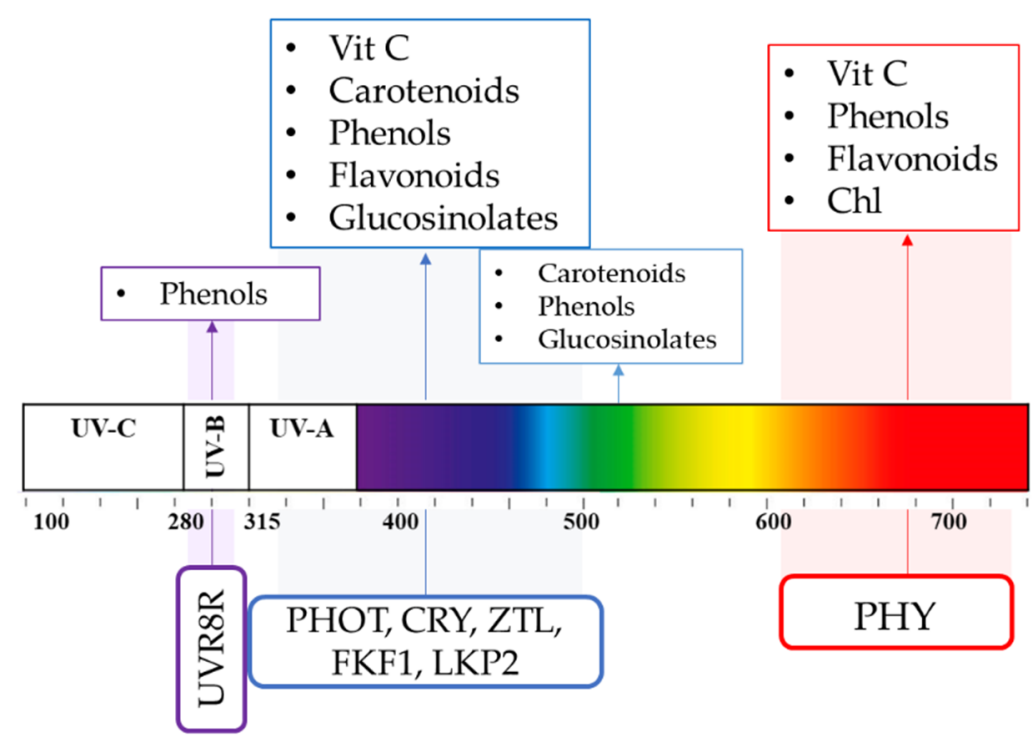

Figure 6. Photoreceptor-mediated effects on plant antioxidant compounds, namely, vitamin C, carotenoids, phenols, chlorophylls, flavonoids, and glucosinolates. Higher font dimension indicates a higher modulation. Ultraviolet radiation A (UV-A), ultraviolet radiation B (UV-B), ultraviolet radiation $\mathrm{C}(\mathrm{UV}-\mathrm{C})$, phytochrome (PHY), cryptochrome (CRY), phototropin (PHOT), flavin binding Kelch domain F box protein (FKF1), zeitlupe (ZTL), LOV Kelch protein2 (LKP2), and UV-B resistance locus 8 (UVR8).

Senescence is an unwanted phenomenon which leads to the loss of the nutritional and commercial value of the product. Generally, weight loss, oxidation, loss of pigments, yellowing in green vegetables due to chl degradation, and alteration of transpiration and respiration processes characterize senescence [182]. BL, RL, and GL can directly affect pigment accumulation, the antioxidant status, and photosynthesis, thus slowing senescence and extending the shelf life of fruits and vegetables.

LEDs can be a powerful tool to enhance plant productivity of protected cultures, which are grown with alternative methods to conventional agriculture, such as soilless, aeroponics, or hydroponic systems. For example, strawberry (Fragaria L.) is one of the fruits which is cultivated in controlled environments because of the high economic income they provide, especially early during the season. BL and RL were effectively employed to increase plant biomass and fruit quality [231,232]. Nonetheless, the implementation of LED systems in artificial cultivation environments can provide unique advantages in terms of sustainability, less land usage, and in the future scenario of climate change [233].

Another important implication that has been explored only recently is the impact of LED treatment on the sensory profile of off-season products. The increase in sugars, acids, minerals, and other components due to LED treatment can significantly impact the sensory profile of fruits and vegetables and improve the consumers' acceptance [234].

Even though LEDs found wide application in small-scale and greenhouse production, only few applications in house refrigerators are present currently in the market. In most of the cases, BL, GL, and WL are used to increase vitamin C content, sustain the photosynthetic process, and preserve chlorophyll from oxidation. LEDs application in food science is still in its early days and many possible positive outcomes can be envisioned in the near future (Figure 7). 


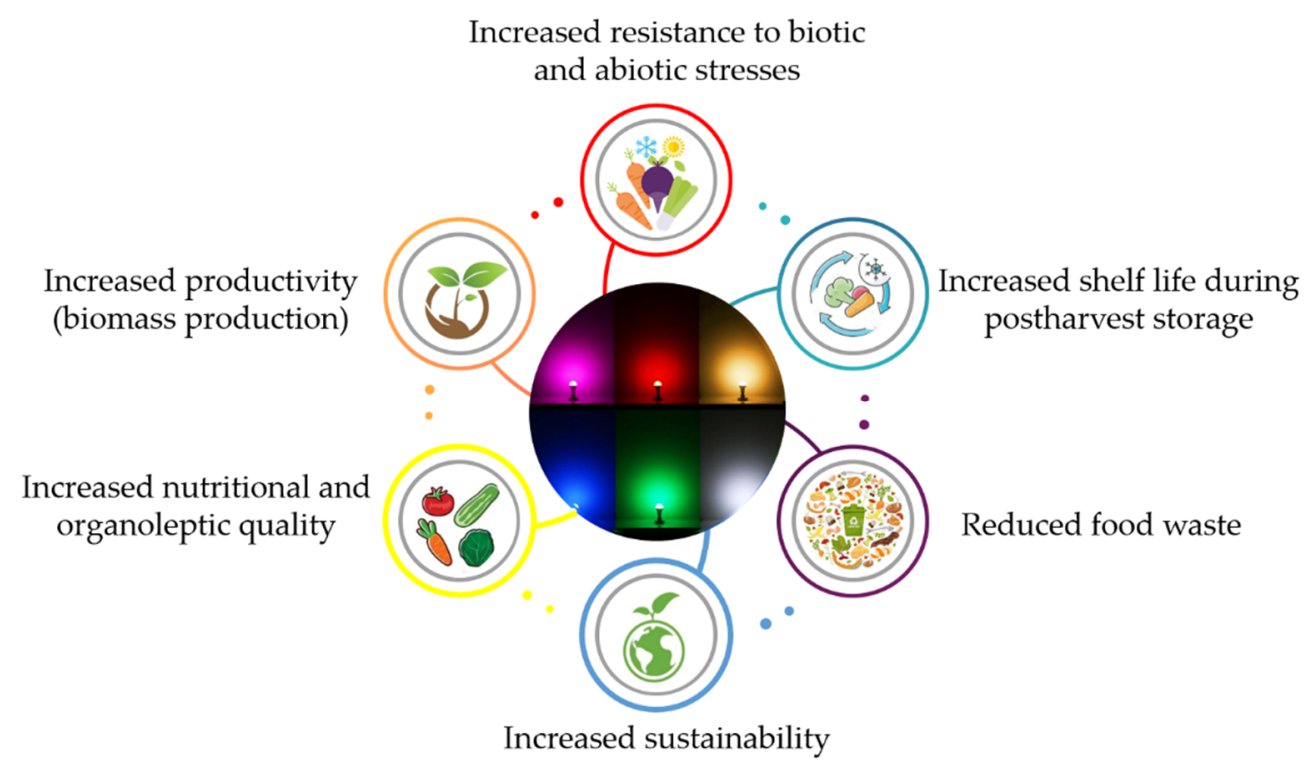

Figure 7. Future perspectives and positive outcomes of LEDs for growth and postharvest storage of food commodities. Further details are given in the text.

\section{Conclusions}

In conclusion, LED technology has shown great potential to promote the growth and the synthesis of beneficial compounds and prolong the shelf life of fruits and vegetables during postharvest storage. So far, a comparison of the studies in the literature is challenging because of the different experimental designs, plant species and cultivars, light types and intensities, and other environmental parameters which are not always fully disclosed or harmonized. Additionally, only recently have quality standards been introduced.

A deeper knowledge of the spectral-dependent responses at the molecular level and the role of photoreceptors can be performed in controlled environments by means of an integrated approach, based on transcriptomics, proteomics, and metabolomics. Data on the plant-LED interaction effects are already available in the literature and, due to the interest of the scientific community, in the next years, a huge amount of data will be continuously added. These data can be analyzed to extrapolate and correlate different types of LED treatment with the fitness of the plant and its antioxidative profile. In this context, artificial intelligence and machine learning algorithms will allow us to predict the plant health and the shelf life of postharvest horticultural crops. Further improvements and studies are therefore essential to design specific LED protocols and enable us to exploit this technology at its fullest potential.

Supplementary Materials: The following are available online at https:/ /www.mdpi.com/2076-392 1/10/1/42/s1, Figure S1: Schematic representation of (A) the L-galactose pathway of vitamin C (Lascorbate) biosynthesis and (B) the Ascorbate-glutathione cycle. Figure S2. Schematic representation of the polyphenol biosynthetic pathway. Figure S3. Schematic representation of the chlorophyll biosynthetic pathway. Figure S4. Schematic representation of the carotenoids biosynthetic pathway. Figure S5. Schematic representation of the glucosinolates biosynthetic pathway.

Author Contributions: Conceptualization, M.L. and C.P.; writing—original draft preparation, M.L., A.V., F.P., G.M., and C.P.; writing-review and editing, M.L., A.V., F.P., G.M., and C.P.; visualization, M.L., A.V., and F.P.; supervision, C.P. and G.M. All authors have read and agreed to the published version of the manuscript.

Funding: This research received no external funding.

Acknowledgments: This work was supported by Research for Innovation (REFIN)—POR PUGLIA FESR-FSE 2014/2020—codice progetto 7B942221—CUP H94I20000410008.

Conflicts of Interest: The authors declare no conflict of interest. 


\section{References}

1. Gupta, D.K.; Palma, J.M.; Corpas, F.J. Antioxidants and Antioxidant Enzymes in Higher Plants, 1st ed.; Springer: Cham, Switzerland, 2018.

2. Alrifai, O.; Hao, X.; Marcone, M.F.; Tsao, R. Current review of the modulatory effects of LED lights on photosynthesis of secondary metabolites and future perspectives of microgreen vegetables. J. Agric. Food Chem. 2019, 67, 6075-6090. [CrossRef] [PubMed]

3. Rienks, J.; Barbaresko, J.; Nöthlings, U. Association of polyphenol biomarkers with cardiovascular disease and mortality risk: A systematic review and meta-analysis of observational studies. Nutrients 2017, 9, 415. [CrossRef] [PubMed]

4. Grosso, G.; Micek, A.; Godos, J.; Pajak, A.; Sciacca, S.; Galvano, F.; Giovannucci, E.L. Dietary flavonoid and lignan intake and mortality in prospective cohort studies: Systematic review and dose-response meta-analysis. Am. J. Epidemiol. 2017, 185, 1304-1316. [CrossRef] [PubMed]

5. Grosso, G.; Micek, A.; Godos, J.; Sciacca, S.; Pajak, A.; Martínez-González, M.A.; Giovannucci, E.L.; Galvano, F. Coffee consumption and risk of all-cause, cardiovascular, and cancer mortality in smokers and non-smokers: A dose-response metaanalysis. Eur. J. Epidemiol. 2016, 31, 1191-1205. [CrossRef]

6. EFSA Panel on Dietetic Products, Nutrition and Allergies (NDA). Scientific Opinion on the substantiation of health claims related to cocoa flavanols and protection of lipids from oxidative damage (ID 652, 1372, 1506, 3143), and maintenance of normal blood pressure (ID 1507) pursuant to Article 13(1) of Regulation (EC) No. 1924/2006. EFSA J. 2010, 8, 1792-1813. [CrossRef]

7. EFSA Panel on Dietetic Products, Nutrition and Allergies (NDA). Scientific Opinion on the substantiation of health claims related to polyphenols in olive and protection of LDL particles from oxidative damage (ID 1333, 1638, 1639, 1696, 2865), maintenance of normal blood HDL cholesterol concentrations (ID 1639), maintenance of normal blood pressure (ID 3781), “anti-inflammatory properties" (ID 1882), "contributes to the upper respiratory tract health" (ID 3468), "can help to maintain a normal function of gastrointestinal tract" (3779), and "contributes to body defences against external agents" (ID 3467) pursuant to Article 13(1) of Regulation (EC) No 1924/2006. EFSA J. 2011, 9, 2033. [CrossRef]

8. Hasanuzzaman, M.; Bhuyan, M.H.M.; Anee, T.I.; Parvin, K.; Nahar, K.; Mahmud, J.A.; Fujita, M. Regulation of ascorbateglutathione pathway in mitigating oxidative damage in plants under abiotic stress. Antioxidants 2019, 8, 384. [CrossRef]

9. Biswas, K.; Adhikari, S.; Tarafdar, A.; Kumar, R.; Saha, S.; Ghosh, P. Reactive Oxygen Species and Antioxidant Defence Systems in Plants: Role and Crosstalk Under Biotic Stress. In Sustainable Agriculture in the Era of Climate Change; Roychowdhury, R., Choudhury, S., Hasanuzzaman, M., Srivastava, S., Eds.; Springer: Cham, Switzerland, 2020; Chapter 12; pp. 265-292. [CrossRef]

10. Kumar, N.; Singh, K.; Sharma, S.K. Antioxidants: Responses and Importance in Plant Defense System. In Sustainable Agriculture in the Era of Climate Change; Roychowdhury, R., Choudhury, S., Hasanuzzaman, M., Srivastava, S., Eds.; Springer: Cham, Switzerland, 2020; Chapter 11; pp. 251-264. [CrossRef]

11. Dou, H.; Niu, G.; Gu, M.; Masabni, J.G. Effects of light quality on growth and phytonutrient accumulation of herbs under controlled environments. Horticulturae 2017, 3, 36. [CrossRef]

12. Dou, H.; Niu, G. Plant responses to light. In Plant Factory, 2nd ed.; Kozai, T., Niu, G., Takagaki, G., Eds.; Academic Press: London, UK, 2020; Chapter 9; pp. 153-166. [CrossRef]

13. Yao, H.; Zhang, Y.; Yi, X.; Zuo, W.; Lei, Z.; Sui, L.; Zhang, W. Characters in light-response curves of canopy photosynthetic use efficiency of light and $\mathrm{N}$ in responses to plant density in field-grown cotton. Field Crops Res. 2017, 203, 192-200. [CrossRef]

14. Stagnari, F.; Di Mattia, C.; Galieni, A.; Santarelli, V.; D’Egidio, S.; Pagnani, G.; Pisante, M. Light quantity and quality supplies sharply affect growth, morphological, physiological and quality traits of basil. Ind. Crop. Prod. 2018, 122, 277-289. [CrossRef]

15. Taulavuori, K.; Hyöky, V.; Oksanen, J.; Taulavuori, E.; Julkunen-Tiitto, R. Species-specific differences in synthesis of flavonoids and phenolic acids under increasing periods of enhanced blue light. Environ. Exp. Bot. 2016, 121, 145-150. [CrossRef]

16. Demotes-Mainard, S.; Péron, T.; Corot, A.; Bertheloot, J.; Le Gourrierec, J.; Pelleschi-Travier, S.; Crespel, L.; Morela, P.; HuchéThélier, L.; Boumaza, R.; et al. Plant responses to red and far-red lights, applications in horticulture. Environ. Exp. Bot. 2016, 121, 4-21. [CrossRef]

17. Pinnola, A.; Bassi, R. Molecular mechanisms involved in plant photoprotection. Biochem. Soc. Trans. 2018, 46, 467-482. [CrossRef] [PubMed]

18. Paik, I.; Huq, E. Plant photoreceptors: Multi-functional sensory proteins and their signaling networks. Semin. Cell Dev. Biol. 2019, 92, 114-121. [CrossRef]

19. Ibaraki, Y. LED supplementary lighting. In Light Emitting Diodes for Agriculture, 1st ed.; Dutta Gupta, S., Ed.; Springer: Singapore, 2017; Chapter 2; pp. 27-36. [CrossRef]

20. Oncel, S.S.; Kose, A.; Vardar, F.; Torzillo, G. From the ancient tribes to modern societies, microalgae evolution from a simple food to an alternative fuel source. In Handbook of Marine Microalgae, 1st ed.; Se-Kwon, K., Ed.; Academic Press: Cambridge, MA, USA, 2015; pp. 127-144.

21. Bantis, F.; Smirnakou, S.; Ouzounis, T.; Koukounaras, A.; Ntagkas, N.; Radoglou, K. Current status and recent achievements in the field of horticulture with the use of light-emitting diodes (LEDs). Sci. Hortic. 2018, 235, 437-451. [CrossRef]

22. Lee, S.W.; Seo, J.M.; Lee, M.K.; Chun, J.H.; Antonisamy, P.; Arasu, M.V.; Suzuki, T.; Al-Dhabi, N.A.; Kim, S.J. Influence of different LED lamps on the production of phenolic compounds in common and Tartary buckwheat sprouts. Ind. Crops Prod. 2014, 54, 320-326. [CrossRef]

23. Wilson, J.; Hawkes, J. Display devices. In Optoelectronics, an Introduction, 3rd ed.; Prentice Hall PTR: Saddle River, NJ, USA, 1998; pp. 129-167. ISBN 0521771293. 
24. Schubert, E.F. LED basics: Optical properties. In Light-Emitting Diodes, 2nd ed.; Cambridge University Press: Cambridge, UK, 2006; pp. 86-190. ISBN 9780521865388.

25. Rosencher, E.; Vinter, B. Light emitting diodes and laser diodes. In Optoelectronics, English Edition; Cambridge University Press: Cambridge, UK, 2004; pp. 613-656. ISBN B001FB6DT0.

26. Pimputkar, S.; Speck, J.; Denbaars, S. Prospects for LED lighting. Nat. Photonics 2009, 3, 180-182. [CrossRef]

27. How Do LEDs Work?-Patterned Sapphire Substrates. Available online: https://www.mikewoodconsulting.com/articles/ Protocol\%20Fall\%202016\%20-\%20Patterned\%20Sapphire\%20Substrates.pdf (accessed on 4 November 2020).

28. Franklin, K.A.; Quail, P.H. Phytochrome functions in Arabidopsis development. J. Exp. Bot. 2010, 61, 11-24. [CrossRef]

29. Lin, C.; Shalitin, D. Cryptochrome Structure and Signal Transduction. Annu. Rev. Plant Biol. 2003, 54, 469-496. [CrossRef]

30. Christie, J.M. Phototropin blue-light receptors. Annu. Rev. Plant Biol. 2007, 58, 21-45. [CrossRef]

31. Kim, W.Y.; Fujiwara, S.; Suh, S.S.; Kim, J.; Kim, Y.; Han, L.; David, K.; Putterill, J.; Nam, H.G.; Somers, D.E. ZEITLUPE is a circadian photoreceptor stabilized by GIGANTEA in blue light. Nature 2007, 449, 356-360. [CrossRef] [PubMed]

32. Zoltowski, B.D.; Imaizumi, T. Structure and function of the ZTL/FKF1/LKP2 group proteins in Arabidopsis. Enzymes 2014, 35, 213-239. [CrossRef] [PubMed]

33. Rizzini, L.; Favory, J.J.; Cloix, C.; Faggionato, D.; O’Hara, A.; Kaiserli, E.; Baumeister, R.; Schäfer, E.; Nagy, F.; Jenkins, G.I.; et al. Perception of UV-B by the Arabidopsis UVR8 protein. Science 2011, 332, 103-106. [CrossRef] [PubMed]

34. Tilbrook, K.; Arongaus, A.B.; Binkert, M.; Heijde, M.; Yin, R.; Ulm, R. The UVR8 UV-B Photoreceptor: Perception, Signaling and Response. Arab. Book 2013, 11, e0164. [CrossRef] [PubMed]

35. Christie, J.M.; Blackwood, L.; Petersen, J.; Sullivan, S. Plant flavoprotein photoreceptors. Plant Cell Physiol. 2015, 56, 401-413. [CrossRef] [PubMed]

36. Shimazaki, K.I.; Doi, M.; Assmann, S.M.; Kinoshita, T. Light regulation of stomatal movement. Annu. Rev. Plant Biol. 2007, 58, 219-247. [CrossRef]

37. Wang, Q.; Zuo, Z.; Wang, X.; Liu, Q.; Gu, L.; Oka, Y.; Lin, C. Beyond the photocycle-How cryptochromes regulate photoresponses in plants? Curr. Opin. Plant Biol. 2018, 45, 120-126. [CrossRef]

38. Fiorucci, A.S.; Fankhauser, C. Plant Strategies for Enhancing Access to Sunlight. Curr. Biol. 2017, 27, R931-R940. [CrossRef]

39. Nozue, K.; Covington, M.; Duek, P.; Lorrain, S.; Fankhauser, C.; Harmer, S.L.; Maloof, J.N. Rhythmic growth explained by coincidence between internal and external cues. Nature 2007, 448, 358-361. [CrossRef]

40. Kinoshita, T.; Doi, M.; Suetsugu, N.; Kagawa, T.; Wada, M.; Shimazaki, K.I. phot1 and phot2 mediate blue light regulation of stomatal opening. Nature 2001, 414, 656-660. [CrossRef]

41. Imaizumi, T.; Tran, H.G.; Swartz, T.E.; Briggs, W.R.; Kay, S.A. FKF1 is essential for photoperiodic-specific light signalling in Arabidopsis. Nature 2003, 426, 302-306. [CrossRef] [PubMed]

42. Baudry, A.; Ito, S.; Song, Y.H.; Strait, A.A.; Kiba, T.; Lu, S.; Henriques, R.; Pruneda-Paz, J.L.; Chua, N.H.; Tobin, E.M.; et al. F-box proteins FKF1 and LKP2 act in concert with ZEITLUPE to control Arabidopsis clock progression. Plant Cell 2010, 22, 606-622. [CrossRef] [PubMed]

43. Li, J.; Li, G.; Wang, H.; Wang Deng, X. Phytochrome signaling mechanisms. Arab. Book 2011, 9, e0148. [CrossRef] [PubMed]

44. Yano, A.; Fujiwara, K. Plant lighting system with five wavelength-band light-emitting diodes providing photon flux density and mixing ratio control. Plant Methods 2012, 8, 46. [CrossRef]

45. Foyer, C.H.; Noctor, G. Oxygen processing in photosynthesis: Regulation and signalling. New Phytol. 2000, 146, 359-388. [CrossRef]

46. Foyer, C.H.; Noctor, G. Redox regulation in photosynthetic organisms: Signaling, acclimation, and practical implications. Antioxid. Redox Sign. 2009, 11, 861-905. [CrossRef]

47. Gallie, D.R. The role ofL-ascorbic acid recycling in responding to environmental stress and in promoting plant growth. J. Exp. Bot. 2013, 64, 433-443. [CrossRef]

48. Paciolla, C.; Fortunato, S.; Dipierro, N.; Paradiso, A.; De Leonardis, S.; Mastropasqua, L.; de Pinto, M.C. Vitamin C in Plants: From Functions to Biofortification. Antioxidants 2019, 8, 519. [CrossRef]

49. Ortiz-Espín, A.; Sánchez-Guerrero, A.; Sevilla, F.; Jiménez, A. The role of ascorbate in plant growth and development. In Ascorbic Acid in Plant Growth, Development and Stress Tolerance; Hossain, M.A., Munnè-Bosch, S., Burritt, D.J., Diaz-Vivancos, P., Fujita, M., Lorence, A., Eds.; Springer: Cham, Switzerland, 2017; pp. 25-45.

50. Wheeler, G.L.; Jones, M.A.; Smirnoff, N. The biosynthetic pathway of vitamin C in higher plants. Nature 1998, 393, 365-369. [CrossRef]

51. Chambial, S.; Dwivedi, S.; Shukla, K.K.; John, P.J.; Sharma, P. Vitamin C in disease prevention and cure: An overview. Indian J. Clin. Biochem. 2013, 28, 314-328. [CrossRef]

52. Williamson, G.; Rhodes, M.J.C.; Parr, A.J. Disease prevention and plant dietary substances. In Chemicals from Plants. Perspectives on Plant Secondary Products; Waltonand, N.J., Brown, D.E., Eds.; Imperial College Press and World Scientific Publishing Co. Pte. Ltd.: London, UK, 1999; pp. 251-276. ISBN 981-02-2773-6.

53. Bartoli, C.G.; Tambussi, E.A.; Diego, F.; Foyer, C.H. Control of ascorbic acid synthesis and accumulation and glutathione by the incident light red/far red ratio in Phaseolus vulgaris leaves. FEBS Lett. 2009, 583, 118-122. [CrossRef] [PubMed]

54. Mastropasqua, L.; Borraccino, G.; Bianco, L.; Paciolla, C. Light qualities and dose influence ascorbate pool size in detached oat leaves. Plant Sci. 2012, 183, 57-64. [CrossRef] [PubMed] 
55. Ma, G.; Zhang, L.; Setiawan, C.K.; Yamawaki, K.; Asai, T.; Nishikawa, F.; Maezawa, S.; Sato, H.; Kanemitsu, N.; Kato, M. Effect of red and blue LED light irradiation on ascorbate content and expression of genes related to ascorbate metabolism in postharvest broccoli. Postharvest Biol. Technol. 2014, 94, 97-103. [CrossRef]

56. Loi, M.; Liuzzi, V.C.; Fanelli, F.; De Leonardis, S.; Creanza, T.M.; Ancona, N.; Paciolla, C.; Mulè, G. Effect of different light-emitting diode (LED) irradiation on the shelf life and phytonutrient content of broccoli (Brassica oleracea L. var. italica). Food Chem. 2019, 283, 206-214. [CrossRef]

57. Mastropasqua, L.; Tanzarella, P.; Paciolla, C. Effects of postharvest light spectra on quality and health-related parameters in green Asparagus officinalis L. Postharvest Biol. Technol. 2016, 112, 143-151. [CrossRef]

58. Mastropasqua, L.; Dipierro, N.; Paciolla, C. Effects of Darkness and Light Spectra on Nutrients and Pigments in Radish, Soybean, Mung Bean and Pumpkin Sprouts. Antioxidants 2020, 9, 558. [CrossRef]

59. Dutilleul, C.; Garmier, M.; Noctor, G.; Mathieu, C.; Chétrit, P.; Foyer, C.H.; de Paepe, R. Leaf mitochondria modulate whole cell redox homeostasis, set antioxidant capacity, and determine stress resistance through altered signaling and diurnal regulation. Plant Cell 2003, 15, 1212-1226. [CrossRef]

60. Tamaoki, M.; Mukai, F.; Asai, N.; Nakajima, N.; Kubo, A.; Aono, M.; Saji, H. Light-controlled expression of a gene encodingLgalactono-lactone dehydrogenase which affects ascorbate pool size in Arabidopsis thaliana. Plant Sci. 2003, 164, $1111-1117$. [CrossRef]

61. Massot, C.; Génard, M.; Stevens, R.; Gautier, H. Fluctuations in sugar content are not determinant in explaining variations in vitamin C in tomato fruit. Plant Physiol. Biochem. 2010, 48, 751-757. [CrossRef]

62. Truffault, V.; Fry, S.C.; Stevens, R.G.; Gautier, H. Ascorbate degradation in tomato leads to accumulation of oxalate, threonate and oxalyl threonate. Plant J. 2017, 89, 996-1008. [CrossRef]

63. Smirnoff, N.; Pallanca, J.E. Ascorbate metabolism in relation to oxidative stress. Biochem. Soc Trans. 1996, 24, 472-478. [CrossRef] [PubMed]

64. Wang, J.; Yu, Y.; Zhang, Z.; Quan, R.; Zhang, H.; Ma, L.; Deng, X.W.; Huang, R. Arabidopsis CSN5B interacts with VTC1 and modulates ascorbic acid synthesis. Plant Cell 2013, 25, 625-636. [CrossRef] [PubMed]

65. Yabuta, Y.; Mieda, T.; Rapolu, M.; Nakamura, A.; Motoki, T.; Maruta, T.; Yoshimura, K.; Ishikawa, T.; Shigeoka, S. Light regulation of ascorbate biosynthesis is dependent on the photosynthetic electron transport chain but independent of sugars in Arabidopsis. J. Exp. Bot. 2007, 58, 2661-2671. [CrossRef] [PubMed]

66. Di Matteo, A.; Sacco, A.; Anacleria, M.; Pezzotti, M.; Delledonne, M.; Ferrarini, A.; Frusciante, L.; Barone, A. The ascorbic acid content of tomato fruits is associated with the expression of genes involved in pectin degradation. BMC Plant Biol. 2010, 10, 163. [CrossRef] [PubMed]

67. Ntagkas, N.; Woltering, E.; Bouras, S.; de Vos, R.C.; Dieleman, J.A.; Nicole, C.C.; Labrie, C.; Marcelis, L.F. Light-induced vitamin c accumulation in tomato fruits is independent of carbohydrate availability. Plants 2019, 8, 86. [CrossRef]

68. Müller-Moulé, P.; Golan, T.; Niyogi, K.K. Ascorbate-deficient mutants of Arabidopsis grow in high light despite chronic photooxidative stress. Plant Physiol. 2014, 133, 748-760. [CrossRef]

69. Karpinska, B.; Zhang, K.; Rasool, B.; Pastok, D.; Morris, J.; Verrall, S.; Hedley, P.E.; Hancock, R.D.; Foyer, C.H. The redox state of the apoplast influences the acclimation of photosynthesis and leaf metabolism to changing irradiance. Plant Cell Environ. 2017, 41, 1083-1097. [CrossRef]

70. Massot, C.; Stevens, R.; Genard, M.; Longuenesse, J.J.; Gautier, H. Light affects ascorbate content and ascorbate-related gene expression in tomato leaves more than in fruits. Planta 2012, 235, 153-163. [CrossRef]

71. Tabata, K.; Takaoka, T.; Esaka, M. Gene expression of ascorbic acid-related enzymes in tobacco. Phytochemistry 2002, 61, 631-635. [CrossRef]

72. Zhang, L.; Ma, G.; Yamawaki, K.; Ikoma, Y.; Matsumoto, H.; Yoshioka, T.; Ikoma, Y.; Matsumoto, H.; Yoshioka, T.; Ohta, S.; et al. Regulation of ascorbic acid metabolism by blue LED light irradiation in citrus juice sacs. Plant Sci. 2015, 233, 134-142. [CrossRef]

73. Song, Y.; Qiu, K.; Gao, J.; Kuai, B. Molecular and physiological analyses of the effects of red and blue LED light irradiation on postharvest senescence of pak choi. Postharvest Biol. Technol. 2020, 164, 111155. [CrossRef]

74. Wang, X.; Wang, H.; Wang, J.; Sun, R.; Wu, J.; Liu, S.; Bai, Y.; Mun, J.H.; Bancroft, I.; Cheng, F.; et al. The genome of the mesopolyploid crop species Brassica rapa. The Brassica rapa Genome Sequencing Project Consortium. Nat. Genet. 2011, 43, 1035-1039. [CrossRef] [PubMed]

75. Xu, F.; Shi, L.; Chen, W.; Cao, S.; Su, Z.; Yang, Z. Effect of blue light treatment on fruit quality, antioxidant enzymes and radical-scavenging activity in strawberry fruit. Sci. Hortic. 2014, 175, 181-186. [CrossRef]

76. Yan, Z.N.; He, D.X.; Niu, G.H.; Zhou, Q.; Qu, Y.H. Growth, nutritional quality, and energy use efficiency in two lettuce cultivars as influenced by white plus red versus red plus blue LEDs. Int. J. Agric. Biol. Eng. 2020, 13, 33-40. [CrossRef]

77. Zha, L.; Liu, W.; Yang, Q.; Zhang, Y.; Zhou, C.; Shao, M. Regulation of Ascorbate Accumulation and Metabolism in Lettuce by the Red:Blue Ratio of Continuous Light Using LEDs. Front. Plant Sci. 2020, 11, 704. [CrossRef]

78. Li, H.M.; Tang, C.M.; Xu, Z.G.; Liu, X.Y.; Han, X.L. Effects of different light sources on the growth of non-heading Chinese cabbage (Brassica campestris L.). J. Agric. Sci. 2012, 4, 262-273. [CrossRef]

79. Yang, X.J.; Liu, S.Q.; Zhang, Z.K.; Ma, L.; Zhang, Y.; Wei, H. Effects of different light emitting diode sources on nutritional quality of garlic seedling. Acta Nutr. Sin. 2010, 32, 518-520. 
80. Zhang, L.W.; Liu, S.Q.; Zhang, Z.K.; Yang, R.; Yang, X.J. Dynamic effects of different light qualities on pea sprouts quality. North. Hortic. 2010, 8, 4-7.

81. Samuolienè, G.; Urbonavičiūtè, A.; Brazaitytè, A.; Šabajevienè, G.; Sakalauskaitè, J.; Duchovskis, P. The impact of LED illumination on antioxidant properties of sprouted seeds. Cent. Eur. J. Biol. 2011, 6, 68-74. [CrossRef]

82. Ntagkas, N.; Min, Q.; Woltering, E.J.; Labrie, C.; Nicole, C.C.S.; Marcelis, L.F.M. Illuminating tomato fruit enhances fruit vitamin C content. Acta Hortic. 2016, 1134, 351-356. [CrossRef]

83. Saengtharatip, S.; Goto, N.; Kozai, T.; Yamori, W. Green light penetrates inside crisp head lettuce leading to chlorophyll and ascorbic acid content enhancement. Acta Hortic. 2020, 1273, 261-270. [CrossRef]

84. Kokalj, D.; Hribar, J.; Cigic, B.; Zlatic, E.; Demsar, L.; Sinkovic, L.; Sircelj, H.; Bizjak, G.; Vidrih, R. Influence of yellow light-emitting diodes at $590 \mathrm{~nm}$ on storage of apple, tomato and bell pepper fruit. Food Technol. Biotechnol. 2016, 54, 228-235. [CrossRef] [PubMed]

85. Lee, Y.J.; Ha, J.Y.; Oh, J.E.; Cho, M.S. The effect of LED irradiation on the quality of cabbage stored at a low temperature. Food Sci. Biotechnol. 2014, 23, 1087-1093. [CrossRef]

86. Pandey, K.B.; Rizvi, S.I. Plant polyphenols as dietary antioxidants in human health and disease. Oxid. Med. Cell. Longev. 2009, 5, 270-278. [CrossRef]

87. $\mathrm{Xu}, \mathrm{Z}$.; Rothstei, S.J. ROS-Induced anthocyanin production provides feedback protection by scavenging ROS and maintaining photosynthetic capacity in Arabidopsis. Plant Signal Behav. 2018, 13. [CrossRef]

88. Zhang, Z.Z.; Li, X.X.; Chu, Y.N.; Zhang, M.X.; Wen, Y.Q.; Duan, C.Q.; Pan, Q.H. Three types of ultraviolet irradiation differentially promote expression of shikimate pathway genes and production of anthocyanins in grape berries. Plant. Physiol. Biochem. 2012, 57, 74-83. [CrossRef]

89. Xu, J.; Su, X.; Li, Y.; Sun, X.; Wang, D.; Wang, W. Response of bioactive phytochemicals in vegetables and fruits to environmental factors. Eur. J. Nutr. Food Saf. 2019, 9, 233-247. [CrossRef]

90. Sharma, A.; Shahzad, B.; Rehman, A.; Bhardwaj, R.; Landi, M.; Zheng, B. Response of phenylpropanoid pathway and the role of polyphenols in plants under abiotic stress. Molecules 2019, 24, 2452. [CrossRef]

91. Acharya, J.; Rechner, O.; Neugart, S.; Schreiner, M.; Poehling, H.M. Effects of light-emitting diode treatments on Brevicoryne brassicae performance mediated by secondary metabolites in Brussels sprouts. J. Plant Dis. Prot. 2016, 123, 321-330. [CrossRef]

92. Nam, T.G.; Kim, D.O.; Eom, S.H. Effects of light sources on major flavonoids and antioxidant activity in common buckwheat sprouts. Food Sci. Biotechnol. 2018, 27, 169-176. [CrossRef]

93. Taulavuori, K.; Pyysalo, A.; Taulavuori, E.; Julkunen-Tiitto, R. Responses of phenolic acid and flavonoid synthesis to blue and blue-violet light depends on plant species. Environ. Exp. Bot. 2018, 150, 183-187. [CrossRef]

94. Kim, E.; Park, S.; Park, B.; Lee, Y.; Oh, M.M. Growth and antioxidant phenolic compounds in cherry tomato seedlings grown under monochromatic light-emitting diodes. Hortic. Environ. Biotechnol. 2014, 55, 506-513. [CrossRef]

95. Wang, P.; Chen, S.; Gu, M.; Chen, X.; Chen, X.; Yang, J.; Ye, N. Exploration of the Effects of Different Blue LED Light Intensities on Flavonoid and Lipid Metabolism in Tea Plants via Transcriptomics and Metabolomics. Int. J. Mol. Sci. 2020, 21, 4606. [CrossRef] [PubMed]

96. Amoozgar, A.; Mohammadi, A.; Sabzalian, M.R. Impact of light-emitting diode irradiation on photosynthesis, phytochemical composition and mineral element content of lettuce cv. Grizzly. Photosynthetica 2017, 55, 85-95. [CrossRef]

97. Xie, D.; Chen, L.; Zhou, C.; Tarin, M.W.K.; Yang, D.; Ren, K.; Zheng, Y. Transcriptomic and metabolomic profiling reveals the effect of LED light quality on morphological traits, and phenylpropanoid-derived compounds accumulation in Sarcandra glabra seedlings. BMC Plant Biol. 2020, 20, 1-18. [CrossRef] [PubMed]

98. Liu, S.; Hu, L.; Jiang, D.; Xi, W. Effect of Post-Harvest LED and UV Light Irradiation on the Accumulation of Flavonoids and Limonoids in the Segments of Newhall Navel Oranges (Citrus sinensis Osbeck). Molecules 2019, 24, 1755. [CrossRef]

99. Li, H.; Lin, Y.; Chen, X.; Bai, Y.; Wang, C.; Xu, X.; Lai, Z. Effects of blue light on flavonoid accumulation linked to the expression of miR393, miR394 and miR395 in longan embryogenic calli. PLoS ONE 2018, 13, e0191444. [CrossRef]

100. Kokalj, D.; Zlatić, E.; Cigić, B.; Vidrih, R. Postharvest light-emitting diode irradiation of sweet cherries (Prunus avium L.) promotes accumulation of anthocyanins. Postharvest Biol. Technol. 2019, 148, 192-199. [CrossRef]

101. Maroga, G.M.; Soundy, P.; Sivakumar, D. Different Postharvest Responses of Fresh-Cut Sweet Peppers Related to Quality and Antioxidant and Phenylalanine Ammonia Lyase Activities during Exposure to Light-Emitting Diode Treatments. Foods 2019, 8, 359. [CrossRef]

102. Wilawan, N.; Ngamwonglumlert, L.; Devahastin, S.; Chiewchan, N. Changes in enzyme activities and amino acids and their relations with phenolic compounds contents in okra treated by LED lights of different colors. Food Bioprocess Technol. 2019, 12, 1945-1954. [CrossRef]

103. Ahn, S.Y.; Kim, S.A.; Yun, H.K. Inhibition of Botrytis cinerea and accumulation of stilbene compounds by light-emitting diodes of grapevine leaves and differential expression of defense-related genes. Eur. J. Plant Pathol. 2015, 143, 753-765. [CrossRef]

104. Gam, D.T.; Khoi, P.H.; Ngoc, P.B.; Linh, L.K.; Hung, N.K.; Anh, P.T.L.; Ha, C.H. LED Lights Promote Growth and Flavonoid Accumulation of Anoectochilus roxburghii and Are Linked to the Enhanced Expression of Several Related Genes. Plants 2020, 9, 1344. [CrossRef] [PubMed]

105. Gupta, S.D.; Pradhan, S. Regulation of gene expression by LED lighting. In Light Emitting Diodes for Agriculture, 1st ed.; Dutta Gupta, S., Ed.; Springer: Singapore, 2017; Chapter 10; pp. 237-258. 
106. Liu, J.; Osbourn, A.; Ma, P. MYB transcription factors as regulators of phenylpropanoid metabolism in plants. Mol. Plant 2015, 8, 689-708. [CrossRef] [PubMed]

107. Huang, J.Y.; Xu, F.; Zhou, W. Effect of LED irradiation on the ripening and nutritional quality of postharvest banana fruit. J. Sci. Food Agric. 2018, 98, 5486-5493. [CrossRef] [PubMed]

108. Jin, P.; Yao, D.; Xu, F.; Wang, H.; Zheng, Y. Effect of light on quality and bioactive compounds in postharvest broccoli florets. Food Chem. 2015, 172, 705-709. [CrossRef] [PubMed]

109. Samuolienè, G.; Viršilè, A.; Brazaitytè, A.; Jankauskienė, J.; Sakalauskienè, S.; Vaštakaitè, V.; Novickovas, A.; Viškeliene, A.; Sasnauskas, A.; Duchovskisa, P.; et al. Blue light dosage affects carotenoids and tocopherols in microgreens. Food Chem. 2017, 228, 50-56. [CrossRef] [PubMed]

110. Son, K.H.; Oh, M.M. Leaf shape, growth, and antioxidant phenolic compounds of two lettuce cultivars grown under various combinations of blue and red light-emitting diodes. HortScience 2013, 48, 988-995. [CrossRef]

111. Ouzounis, T.; Razi Parjikolaei, B.; Fretté, X.; Rosenqvist, E.; Ottosen, C.O. Predawn and high intensity application of supplemental blue light decreases the quantum yield of PSII and enhances the amount of phenolic acids, flavonoids, and pigments in Lactuca sativa. Front. Plant Sci. 2015, 6, 19. [CrossRef]

112. Liu, H.; Chen, Y.; Hu, T.; Zhang, S.; Zhang, Y.; Zhao, T.; Kang, Y. The influence of light-emitting diodes on the phenolic compounds and antioxidant activities in pea sprouts. J. Funct. Food 2016, 25, 459-465. [CrossRef]

113. Park, C.H.; Kim, N.S.; Park, J.S.; Lee, S.Y.; Lee, J.W.; Park, S.U. Effects of light-emitting diodes on the accumulation of glucosinolates and phenolic compounds in sprouting canola (Brassica napus L.). Foods 2019, 8, 76. [CrossRef]

114. Lichtenthaler, H.K. Chlorophylls and carotenoids: Pigments of photosynthetic biomembranes. Methods Enzymol. 1987, 148, 350-382. [CrossRef]

115. Gross, J. Pigments in Vegetables: Chlorophylls and Carotenoids; Springer Science \& Business Media: New York, NY, USA, 2012; ISBN 1461520339.

116. Croft, H.; Chen, J.M. Leaf pigment content. In Reference Module in Earth Systems and Environmental Sciences; Elsevier Inc.: Oxford, UK, 2017; pp. 1-22.

117. Von Wettstein, D.; Gough, S.; Kannangara, C.G. Chlorophyll biosynthesis. Plant Cell 1995, 7, 1039-1057. [CrossRef]

118. Willows, R.D. Biosynthesis of chlorophylls from protoporphyrin IX. Nat. Prod. Rep. 2003, 20, 327-341. [CrossRef] [PubMed]

119. Masuda, T.; Fujita, Y. Regulation and evolution of chlorophyll metabolism. Photochem. Photobiol. Sci. 2008, 7, 1131-1149. [CrossRef] [PubMed]

120. Stenbaek, A.; Jensen, P.E. Redox regulation of chlorophyll biosynthesis. Phytochemistry 2010, 71, 853-859. [CrossRef] [PubMed]

121. Maoka, T. Carotenoids as natural functional pigments. J. Nat. Med. 2020, 1-16. [CrossRef] [PubMed]

122. Sathasivam, R.; Radhakrishnan, R.; Kim, J.K.; Park, S.U. An update on biosynthesis and regulation of carotenoids in plants. S. Afr. J. Bot. 2020, 1-13. [CrossRef]

123. Hajiboland, R. Reactive oxygen species and photosynthesis. In Oxidative Damage to Plants; Ahmad, A., Ed.; Academic Press: Cambridge, MA, USA, 2014; Chapter 1; pp. 1-63. [CrossRef]

124. Czarnocka, W.; Karpiński, S. Friend or foe? Reactive oxygen species production, scavenging and signaling in plant response to environmental stresses. Free Rad. Biol. Med. 2018, 122, 4-20. [CrossRef]

125. Lado, J.; Alós, E.; Manzi, M.; Cronje, P.J.; Gómez-Cadenas, A.; Rodrigo, M.J.; Zacarías, L. Light regulation of carotenoid biosynthesis in the peel of mandarin and sweet orange fruits. Front. Plant Sci. 2019, 10, 1288. [CrossRef]

126. Schreiber, U.; Bilger, W.; Hormann, H.; Neubauer, C. Chlorophyll fluorescence as diagnostic tool: Basics and some aspects of practical relevance. In Photosynthesis: A Comprehensive Treatise; Raghavendra, A.S., Ed.; Cambridge University Press: Cambridge, UK, 1998; pp. 320-336.

127. Cavender-Bares, J.; Bazzaz, F.A. From leaves to ecosystems: Using chlorophyll fluorescence to assess photosynthesis and plant function in ecological studies. In Chlorophyll a Fluorescence: A Signature of Photosynthesis; Papageorgiou, G.C., Ed.; Springer: Dordrecht, The Netherlands, 2004; pp. 737-755.

128. Van Iersel, M.W. Optimizing LED lighting in controlled environment agriculture. In Light Emitting Diodes for Agriculture: Smart Lighting; Gupta, S.D., Ed.; Springer: Singapore, 2017; pp. 59-80.

129. Pizarro, L.; Stange, C. Light-dependent regulation of carotenoid biosynthesis in plants. Cien. Investig. Agrar. 2009, 36, 143-162. [CrossRef]

130. Li, C.X.; Chang, S.X.; Khalil-Ur-Rehman, M.; Xu, Z.G.; Tao, J.M. Effect of irradiating the leaf abaxial surface with supplemental light-emitting diode lights on grape photosynthesis. Aust. J. Grape Wine Res. 2017, 23, 58-65. [CrossRef]

131. Wu, C.; Sun, L.; Lv, Y.; Cui, H.; Wang, X.; Gao, P.; Luan, F. Functional Characterization and in Silico Analysis of Phytoene Synthase Family Genes Responsible for Carotenoid Biosynthesis in Watermelon (Citrullus lanatus L.). Agronomy 2020, 10, 1077. [CrossRef]

132. Dhingra, A.; Bies, D.H.; Lehner, K.R.; Folta, K.M. Green light adjusts the plastid transcriptome during early photomorphogenic development. Plant Physiol. 2006, 142, 1256-1266. [CrossRef] [PubMed]

133. Reddy, S.K.; Holalu, S.V.; Casal, J.J.; and Finlayson, S.A. Abscisic acid regulates axillary bud outgrowth responses to the ratio of red to far-red light. Plant Physiol. 2013, 163, 1047-1058. [CrossRef]

134. Li, C.X.; Xu, Z.G.; Dong, R.Q.; Chang, S.X.; Wang, L.Z.; Khalil-Ur-Rehman, M.; Tao, J.M. An RNA-seq analysis of grape plantlets grown in vitro reveals different responses to blue, green, red LED light, and white fluorescent light. Front. Plant Sci. $2017,8,78$. [CrossRef] 
135. Ma, G.; Zhang, L.; Kato, M.; Yamawaki, K.; Kiriiwa, Y.; Yahata, M.; Ikoma, Y.; Matsumoto, H. Effect of blue and red LED light irradiation on $\beta$-cryptoxanthin accumulation in the flavedo of citrus fruits. J. Agric. Food Chem. 2012, 60, 197-201. [CrossRef]

136. Ma, G.; Zhang, L.; Kato, M.; Yamawaki, K.; Kiriiwa, Y.; Yahata, M.; Ikoma, Y.; Matsumoto, H. Effect of the combination of ethylene and red LED light irradiation on carotenoid accumulation and carotenogenic gene expression in the flavedo of citrus fruit. Postharvest Biol. Technol. 2015, 99, 99-104. [CrossRef]

137. Llorente, B.; Martinez-Garcia, J.F.; Stange, C.; Rodriguez-Concepcion, M. Illuminating colors: Regulation of carotenoid biosynthesis and accumulation by light. Curr. Opin. Plant Biol. 2017, 37, 49-55. [CrossRef]

138. Tuan, P.A.; Park, C.H.; Park, W.T.; Kim, Y.B.; Kim, Y.J.; Chung, S.O.; Kim, J.K.; Park, S.U. Expression levels of carotenoid biosynthetic genes and carotenoid production in the callus of scutellaria baicalensis exposed to white, blue, and red light-emitting diodes. Appl. Biol. Chem. 2017, 60, 591-596. [CrossRef]

139. Jeon, Y.M.; Son, K.H.; Kim, S.M.; Oh, M.M. Growth and bioactive compounds as affected by irradiation with various spectrum of light-emitting diode lights in dropwort. Hortic. Environ. Biotechnol. 2017, 58, 467-478. [CrossRef]

140. Frede, K.; Schreiner, M.; Baldermann, S. Light quality-induced changes of carotenoid composition in pak choi Brassica rapa ssp. chinensis. J. Photochem. Photobiol. B Biol. 2019, 193, 18-30. [CrossRef] [PubMed]

141. Pola, W.; Sugaya, S.; Photchanachai, S. Color development and phytochemical changes in mature green chili (Capsicum annuum L.) exposed to red and blue light-emitting diodes. J. Agric. Food Chem. 2019, 68, 59-66. [CrossRef] [PubMed]

142. Fan, X.; Zang, J.; Xu, Z.; Guo, S.; Jiao, X.; Liu, X.; Gao, Y. Effects of different light quality on growth, chlorophyll concentration and chlorophyll biosynthesis precursors of non-heading Chinese cabbage (Brassica campestris L.). Acta Physiol. Plant. 2013, 35, 2721-2726. [CrossRef]

143. Lobiuc, A.; Vasilache, V.; Oroian, M.; Stoleru, T.; Burducea, M.; Pintilie, O.; Zamfirache, M.M. Blue and Red LED Illumination Improves Growth and Bioactive Compounds Contents in Acyanic and Cyanic Ocimum basilicum L. Microgreens. Molecules 2017, 22, 2111. [CrossRef]

144. Pennisi, G.; Orsini, F.; Blasioli, S.; Cellini, A.; Crepaldi, A.; Braschi, I.; Spinelli, F.; Nicola, S.; Fernandez, J.A.; Stanghellini, C.; et al. Resource use efficiency of indoor lettuce (Lactuca sativa L.) cultivation as affected by red:blue ratio provided by LED lighting. Sci. Rep. 2019, 9, 14127. [CrossRef]

145. Ghaffari, Z.; Rahimmalek, M.; Sabzalian, M.R. Variation in the primary and secondary metabolites derived from the isoprenoid pathway in the Perovskia species in response to different wavelengths generated by light emitting diodes (LEDs). Ind. Crop Prod. 2019, 140, 1-8. [CrossRef]

146. Fang, L.; Ma, Z.; Wang, Q.; Nian, H.; Ma, Q.; Huang, Q.; Mu, Y. Plant growth and photosynthetic characteristics of soybean seedlings under different led lighting quality conditions. J. Plant Growth Regul. 2020, 1-11. [CrossRef]

147. Chen, X.L.; Guo, W.Z.; Xue, X.Z.; Wang, L.C.; Qiao, X.J. Growth and quality responses of 'Green Oak Leaf' lettuce as affected by monochromic or mixed radiation provided by fluorescent lamp (FL) and light-emitting diode (LED). Sci. Hortic. 2014, 172, 168-175. [CrossRef]

148. Chen, X.L.; Xue, X.Z.; Guo, W.Z.; Wang, L.C.; Qiao, X.J. Growth and nutritional properties of lettuce affected by mixed irradiation of white and supplemental light provided by light-emitting diode. Sci. Hortic. 2016, 200, 111-118. [CrossRef]

149. Kasim, M.U.; Kasim, R. While continuous white LED lighting increases chlorophyll content (SPAD), green LED light reduces the infection rate of lettuce during storage and shelf-life conditions. J. Food Process. Preserv. 2017, 41, 1-7. [CrossRef]

150. Brazaitytè, A.; Sakalauskienè, S.; Samuolienè, G.; Jankauskienè, J.; Viršilè, A.; Novičkovas, A.; Sirtautas, R.; Miliauskienė, J.; Vaštakaite, V.; Dabašinskas, L.; et al. The effects of LED illumination spectra and intensity on carotenoid content in Brassicaceae microgreens. Food Chem. 2015, 173, 600-606. [CrossRef] [PubMed]

151. Darko, É.; Heydarizadeh, P.; Schoefs, B.; Sabzalian, M.R. Photosynthesis under artificial light: The shift in primary and secondary metabolism. Philos. Trans. R. Soc. 2014, 369, 20130243. [CrossRef] [PubMed]

152. Loconsole, D.; Cocetta, G.; Santoro, P.; Ferrante, A. Optimization of LED lighting and quality evaluation of romaine lettuce grown in an innovative indoor cultivation system. Sustainability 2019, 11, 841. [CrossRef]

153. Samuolienè, G.; Brazaitytè, A.; Sirtautas, R.; Viršilè, A.; Sakalauskaitè, J.; Sakalauskienè, S.; Duchovskis, P. LED illumination affects bioactive compounds in romaine baby leaf lettuce. J. Sci. Food Agric. 2013, 93, 3286-3291. [CrossRef] [PubMed]

154. Hu, L.; Yang, C.; Zhang, L.; Feng, J.; Xi, W. Effect of light-emitting diodes and ultraviolet irradiation on the soluble sugar, organic acid, and carotenoid content of postharvest sweet oranges (Citrus sinensis (L.) Osbeck). Molecules 2019, 24, 3440. [CrossRef] [PubMed]

155. Holst, B.; Williamson, G. A critical review of the bioavailability of glucosinolates and related compounds. Nat. Prod. Rep. 2004, 21, 425-447. [CrossRef] [PubMed]

156. Halkier, B.A.; Gershenzon, J. Biology and biochemistry of glucosinolates. Annu. Rev. Plant Biol. 2006, 57, 303-333. [CrossRef]

157. Fahey, J.W.; Zalcmann, A.T.; Talalay, P. The chemical diversity and distribution of glucosinolates and isothiocyanates among plants. Phytochemistry 2001, 56, 5-51. [CrossRef]

158. Mari, M.; Leoni, O.; Iori, R.; Cembali, T. Antifungal vapour-phase activity of allylisothiocyanate against Penicillium expansum on pears. Plant Pathol. 2002, 51, 231-236. [CrossRef]

159. Smith, B.J.; Kirkegaard, J.A. In vitro inhibition of soil microorganisms by 2-phenylethyl isothiocyanate. Plant Pathol. 2002, 51, 585-593. [CrossRef] 
160. Wittstock, U.; Kliebenstein, D.J.; Lambrix, V.M.; Reichelt, M.; Gershenzon, J. Glucosinolate hydrolysis and its impact on generalist and specialist insect herbivores. In Integrative Phytochemistry: From Ethnobotany to Molecular Ecology; Romeo, J.T., Ed.; Elsevier: Amsterdam, The Netherlands, 2003; pp. 101-125.

161. Traka, M.H. Health benefits of glucosinolates. In Glucosinolates, Advances in Botanical Research; Kopriva, S., Ed.; Elsevier: Amsterdam, The Netherlands, 2016; Volume 80, pp. 247-279.

162. Fahey, J.W.; Olson, M.E.; Stephenson, K.K.; Wade, K.L.; Chodur, G.M.; Odee, D.; Nouman, W.; Massiah, M.; Alt, J.; Egner, P.A.; et al. The diversity of chemoprotective glucosinolates in Moringaceae (Moringa spp.). Sci. Rep. 2018, 8, 1-14. [CrossRef] [PubMed]

163. Soundararajan, P.; Kim, J.S. Anti-carcinogenic glucosinolates in cruciferous vegetables and their antagonistic effects on prevention of cancers. Molecules 2018, 23, 2983. [CrossRef] [PubMed]

164. Chang, J.; Wang, M.; Jian, Y.; Zhang, F.; Zhu, J.; Wang, Q.; Sun, B. Health-promoting phytochemicals and antioxidant capacity in different organs from six varieties of Chinese kale. Sci. Rep. 2019, 9, 20344. [CrossRef] [PubMed]

165. Becker, T.M.; Juvik, J.A. The role of glucosinolate hydrolysis products from Brassica vegetable consumption in inducing antioxidant activity and reducing cancer incidence. Diseases 2016, 4, 22. [CrossRef] [PubMed]

166. Groenbaek, M.; Jensen, S.; Neugart, S.; Schreiner, M.; Kidmose, U.; Lakkenborg Kristensen, H. Influence of cultivar and fertilizer approach on curly kale (Brassica oleracea L. var. sabellica). 1. Genetic diversity reflected in agronomic characteristics and phytochemical concentration. J. Agric. Food Chem. 2014, 62, 11393-11402. [CrossRef]

167. Moon, J.; Jeong, M.J.; Lee, S.I.; Lee, J.G.; Hwang, H.; Yu, J.; Kim, Y.-R.; Park, S.W.; Kim, J.A. Effect of LED mixed light conditions on the glucosinolate pathway in brassica rapa. J. Plant Biotechnol. 2015, 42, 245-256. [CrossRef]

168. Qian, H.; Liu, T.; Deng, M.; Miao, H.; Cai, C.; Shen, W.; Wang, Q. Effects of light quality on main health-promoting compounds and antioxidant capacity of Chinese kale sprouts. Food Chem. 2016, 196, 1232-1238. [CrossRef]

169. Groenbaek, M.; Tybirk, E.; Kristensen, H.L. Glucosinolate and carotenoid content of white-and yellow-flowering rapeseed grown for human consumption as sprouts and seedlings under light emitting diodes. Eur. Food Res. Technol. 2018, 244, $1121-1131$. [CrossRef]

170. Mithen, R.; Clarke, J.; Lister, C.; Dean, C. Genetics of aliphatic glucosinolates. III. Side chain structure of aliphatic glucosinolates in Arabidopsis thaliana. Heredity 1995, 74, 210-215. [CrossRef]

171. Giamoustaris, A.; Mithen, R. Genetics of aliphatic glucosinolates IV Side-chain modification in Brassica oleracea. Theor. Appl. Genet. 1996, 93, 1006-1010. [CrossRef]

172. Augustine, R.; Bisht, N. Biofortification of oilseed Brassica juncea with the anti-cancer compound glucoraphanin by suppressing GSL-ALK gene family. Sci. Rep. 2016, 5, 18005. [CrossRef] [PubMed]

173. Kliebenstein, D.J.; Lambrix, V.M.; Reichelt, M.; Gershenzon, J.; Mitchell-Olds, T. Gene duplication in the diversification of secondary metabolism: Tandem 2-oxoglutarate-dependent dioxygenases control glucosinolate biosynthesis in Arabidopsis. Plant Cell 2001, 13, 681-693. [CrossRef] [PubMed]

174. Neal, C.S.; Fredericks, D.P.; Griffiths, C.A.; Neale, A.D. The characterisation of AOP2: A gene associated with the biosynthesis of aliphatic alkenyl glucosinolates in Arabidopsis thaliana. BMC Plant Biol. 2010, 10, 170. [CrossRef] [PubMed]

175. Kopsell, D.A.; Sams, C.E.; Barickman, T.C.; Morrow, R.C. Sprouting broccoli accumulate higher concentrations of nutritionally important metabolites under narrow-band light-emitting diode lighting. J. Am. Soc. Hortic. Sci. 2014, 139, 469-477. [CrossRef]

176. Kopsell, D.A.; Sams, C.E. Increases in shoot tissue pigments, glucosinolates, and mineral elements in sprouting broccoli after exposure to short-duration blue light from light emitting diodes. J. Am. Soc. Hortic. Sci. 2013, 138, 31-37. [CrossRef]

177. Abe, K.; Kido, S.; Maeda, T.; Kami, D.; Matsuura, H.; Shimura, H.; Suzuki, T. Glucosinolate profiles in Cardamine fauriei and effect of light quality on glucosinolate concentration. Sci. Hortic. 2015, 189, 12-16. [CrossRef]

178. Tan, W.K.; Goenadie, V.; Lee, H.W.; Lianga, X.; Loh, C.S.; Ong, C.N.; Tan, H.T.W. Growth and glucosinolate profiles of a common Asian green leafy vegetable, Brassica rapa subsp. Chinensis var. Parachinensis (choy sum), under LED lighting. Sci. Hortic. 2020, 261, 108922. [CrossRef]

179. Mølmann, J.A.; Hansen, E.; Johansen, T.J. Effects of supplemental LED light quality and reduced growth temperature on swede (Brassica napus L. ssp. rapifera Metzg.) root vegetable development and contents of glucosinolates and sugars. J. Sci. Food Agric 2020. [CrossRef]

180. Dutta Gupta, S.; Agarwal, A. Artificial Lighting System for Plant Growth and Development: Chronological Advancement, Working Principles, and Comparative Assessment. In Light Emitting Diodes for Agriculture; Dutta Gupta, S., Ed.; Springer: Singapore, 2017; Chapter 1; pp. 1-25. [CrossRef]

181. Both, A.J.; Bugbee, B.; Kubota, C.; Lopez, R.G.; Mitchell, C.; Runkle, E.S.; Wallace, C. Proposed product label for electric lamps used in the plant sciences. HortTechnology 2017, 27, 544-549. [CrossRef]

182. Nassarawa, S.S.; Abdelshafy, A.M.; Xu, Y.; Li, L.; Luo, Z. Effect of Light-Emitting Diodes (LEDs) on the Quality of Fruits and Vegetables During Postharvest Period: A Review. Food Bioprocess Technol. 2020, 1-27. [CrossRef]

183. Cavaiuolo, M.; Ferrante, A. Nitrates and glucosinolates as strong determinants of the nutritional quality in rocket leafy salads. Nutrients 2014, 6, 1519-1538. [CrossRef] [PubMed]

184. D'Souza, C.; Yuk, H.-G.; Khoo, G.H.; Zhou, W. Application of light-emitting diodes in food production, postharvest preservation, and microbiological food safety. Compr. Rev. Food Sci. Food Saf. 2015, 14, 719-740. [CrossRef]

185. Shi, L.Y.; Cao, S.F.; Chen, W.; Yang, Z.F. Blue light induced anthocyanin accumulation and expression of associated genes in Chinese bayberry fruit. Sci. Hortic. 2014, 179, 98-102. [CrossRef] 
186. Kim, H.H.; Goins, G.D.; Wheeler, R.M.; Sager, J.C. Green-light supplementation for enhanced lettuce growth under red-and blue-light-emitting diodes. HortScience 2004, 39, 1617-1622. [CrossRef]

187. Smith, H.L.; McAusland, L.; Murchie, E.H. Don't ignore the green light: Exploring diverse roles in plant processes. J. Exp. Bot. 2017, 68, 2099-2110. [CrossRef]

188. Vogelmann, T.C. Plant tissue optics. Annu. Rev. Plant Physiol. Plant Mol. Biol. 1993, 44, 231-251. [CrossRef]

189. Johkan, M.; Shoji, K.; Goto, F.; Hahida, S.N.; Yoshihara, T. Effect of green light wavelength and intensity on photomorphogenesis and photosynthesis in Lactuca sativa. Environ. Exp. Bot. 2012, 75, 128-133. [CrossRef]

190. ANSI/ASABE S640: Quantities and Units of Electromagnetic Radiation for Plants. Photosynthetic Organisms; American Society of Agricultural and Biological Engineers: St. Joseph, MI, USA, 2017.

191. ANSI/ASABE S642: Recommended Methods for Measurement and Testing of LED Products for Plant Growth and Development; American Society of Agricultural and Biological Engineers: St. Joseph, MI, USA, 2018.

192. Paucek, I.; Appolloni, E.; Pennisi, G.; Quaini, S.; Gianquinto, G.; Orsini, F. LED Lighting systems for horticulture: Business growth and global distribution. Sustainability 2020, 12, 7516. [CrossRef]

193. Thomas, A.; Nair, A.S. Experimental study on the effect of junction temperature on power LED'S. Int. J. Curr. Eng. Sci. Res. 2015, 2, 14-19.

194. U.S. Department of Energy. Life-Cycle Assessment of Energy and Environmental Impacts of LED Lighting Products, Part 2: LED Manufacturing and Performance. 30 January 2012. Available online: www.yole.fr (accessed on 30 January 2019).

195. Zheng, Y.J.; Zhang, Y.T.; Liu, H.C.; Li, Y.M.; Liu, Y.L.; Hao, Y.W.; Lei, B.F. Supplemental blue light increases growth and quality of greenhouse pak choi depending on cultivar and supplemental light intensity. J. Integr. Agric. 2018, 17, 2245-2256. [CrossRef]

196. Jones-Baumgardt, C.; Llewellyn, D.; Ying, Q.; Zheng, Y. Intensity of sole-source light-emitting diodes affects growth, yield, and quality of Brassicaceae microgreens. HortScience 2019, 54, 1168-1174. [CrossRef]

197. Sipos, L.; Boros, I.F.; Csambalik, L.; Székely, G.; Jung, A.; Balázs, L. Horticultural lighting system optimalization: A review. Sci. Hort. 2020, 273, 109631. [CrossRef]

198. Braidot, E.; Petrussa, E.; Peresson, C.; Patui, S.; Bertolini, A.; Tubaro, F.; Wählby, U.; Coan, M.; Vianello, A.; Zancani, M. Lowintensity light cycles improve the quality of lamb's lettuce (Valerianella olitoria [L.] Pollich) during storage at low temperature. Postharvest Biol. Technol. 2014, 90, 15-23. [CrossRef]

199. Yano, A. Configuration, Function, and Operation of LED Lighting Systems. In LED Lighting for Urban Agriculture; Kozai, T., Fujiwara, K., Runkle, E.S., Eds.; Springer: Singapore, 2016; pp. 403-415.

200. Hernandez, E.; Timmons, M.B.; Mattson, N.S. Quality, Yield, and Biomass Efficacy of Several Hydroponic Lettuce (Lactuca sativa L.) Cultivars in Response to High Pressure Sodium Lights or Light Emitting Diodes for Greenhouse Supplemental Lighting. Horticulturae 2020, 6, 7. [CrossRef]

201. Alrifai, O.; Hao, X.; Liu, R.; Lu, Z.; Marcone, M.F.; Tsao, R. Amber, red and blue LEDs modulate phenolic contents and antioxidant activities in eight Cruciferous microgreens. J. Food Bioact. 2020, 11. [CrossRef]

202. Purschwitz, J.; Müller, S.; Kastner, C.; Fischer, R. Seeing the rainbow: Light sensing in fungi. Curr. Opin. Microbiol. 2006, 9, 566-571. [CrossRef] [PubMed]

203. Dai, T.; Gupta, A.; Huang, Y.Y.; Yin, R.; Murray, C.K.; Vrahas, M.S.; Sherwood, M.E.; Tegos, G.P.; Hamblin, M.R. Blue light rescues mice from potentially Pseudomonas aeruginosa burn infection: Efficacy, safety, and mechanism of action. Antimicrob. Agents Chemother. 2013, 57, 1238-1245. [CrossRef]

204. Huang, L.; Xuan, Y.; Koide, Y.; Zhiyentayev, T.; Sanaka, M.; Hamblin, M.R. Type I and Type II mechanisms of antimicrobial photodynamic therapy. An in vitro study on gram-negative and gram-positive bacteria. Lasers Surg. Med. 2012, 44, 490-499. [CrossRef]

205. Endarko, E.; Maclean, M.; Timoshkin, I.V.; MacGregor, S.J.; Anderson, J.G. High-intensity 405 nm light inactivation of Listeria monocytogenes. Photochem. Photobiol. 2012, 88, 1280-1286. [CrossRef]

206. Imada, K.; Tanaka, S.; Ibaraki, Y.; Yoshimura, K.; Ito, S. Antifungal effect of 405-nm light on Botrytis cinerea. Lett. Appl. Microbiol. 2014, 59, 670-676. [CrossRef]

207. Maclean, M.; McKenzie, K.; Anderson, J.G.; Gettinby, G.; MacGregor, S.J. $405 \mathrm{~nm}$ light technology for the inactivation of pathogens and its potential role for environmental disinfection and infection control. J. Hospital Infect. 2014, 88, 1-11. [CrossRef] [PubMed]

208. Kumar, A.; Ghate, V.; Kim, M.J.; Zhou, W.; Khoo, G.H.; Yuk, H.G. Inactivation and changes in metabolic profile of selected foodborne bacteria by $460 \mathrm{~nm}$ LED illumination. Food Microbiol. 2017, 63, 12-21. [CrossRef] [PubMed]

209. Ballario, P.; Vittorioso, P.; Magrelli, A.; Talora, C.; Cabibbo, A.; Macino, G. White collar-1, a central regulator of blue light responses in Neurospora, is a zinc finger protein. EMBO J. 1996, 15, 1650-1657. [CrossRef] [PubMed]

210. Ballario, P.; Macino, G. White-collar proteins: PASsing the light signal in Neurospora crassa. Trends Microbiol. 1997, 5, 458-462. [CrossRef]

211. Alferez, F.; Liao, H.L.; Burns, J.K. Blue light alters infection by Penicillium digitatum in tangerines. Postharvest Biol. Technol. 2012, 63, 11-15. [CrossRef]

212. Liao, H.L.; Alferez, F.; Burns, J.K. Assessment of blue light treatments on citrus postharvest diseases. Postharvest Biol. Technol. 2013, 81, 81-88. [CrossRef]

213. Lafuente, M.T.; Alferez, F. Effect of LED Blue Light on Penicillium digitatum and Penicillium italicum strains. Photochem. Photobiol. 2015, 91, 1412-1421. [CrossRef] 
214. Yamaga, I.; Takahashi, T.; Ishii, K.; Kato, M.; Kobayashi, Y. Antifungal Effect of Blue LED Irradiation on the Blue Mold, Penicillium italicum, in Satsuma Mandarin Fruits. Hortic. Res. 2015, 14, 83-87. [CrossRef]

215. D'Hallewin, G.; Schirra, M.; Manueddu, E.; Piga, A.; Ben Yehoshua, S. Scoparone and scopoletin accumulation and ultraviolet-C induced resistance to postharvest decay in oranges as influenced by harvest date. J. Am. Soc. Hortic. Sci. 1999, 124, $702-707$. [CrossRef]

216. Marcos, J.F.; González-Candelas, L.; Zacarías, L. Involvement of ethylene biosynthesis and perception in the susceptibility of citrus fruit to Penicillium digitatum infection and the accumulation of defense-related mRNAs. J. Exp. Bot. 2005, 56, $2183-2193$. [CrossRef]

217. Droby, S.; Wisniewski, M.; Macarisin, D.; Wilson, C. Twenty years of postharvest biocontrol research: Is it time for a new paradigm? Postharvest Biol. Technol. 2009, 52, 137-145. [CrossRef]

218. Gonzalez-Candelas, L.; Alamar, S.; Sanchez-Torres, P.; Zacarias, L.; Marcos, J. A transcriptomic approach highlights induction of secondary metabolism in citrus fruit in response to Penicillium digitatum infection. BMC Plant Biol. 2010, 10, 194-211. [CrossRef] [PubMed]

219. Ballester, A.R.; Lafuente, M.T.; de Vos, R.C.H.; Bovy, A.G.; González-Candelas, L. Citrus phenylpropanoids and defense against pathogens. Part I: Metabolic profiling in elicited fruits. Food Chem. 2013, 136, 178-185. [CrossRef] [PubMed]

220. Ballester, A.R.; Lafuente, M.T. LED Blue Light-induced changes in phenolics and ethylene in citrus fruit: Implication in elicited resistance against Penicillium digitatum infection. Food Chem. 2017, 218, 575-583. [CrossRef] [PubMed]

221. Yu, S.M.; Lee, Y.H. Effect of light quality on Bacillus amyloliquefaciens JBC36 and its biocontrol efficacy. Biol. Control 2013, 64, 203-210. [CrossRef]

222. Logrieco, A.; Bottalico, A.; Mulè, G.; Moretti, A.; Perrone, G. Epidemiology of toxigenic fungi and their associated mycotoxins for some Mediterranean crops. Eur. J. Plant Pathol. 2003, 109, 645-667. [CrossRef]

223. Yu, J.J.; Keller, N. Regulation of secondary metabolism in filamentous fungi. Annu. Rev. Phytopathol. 2005, 43, 437-458. [CrossRef]

224. Schmidt-Heydt, M.; Ruefer, C.; Raupp, F.; Bruchmann, A.; Perrone, G.; Geisen, R. Influence of light on food relevant fungi with emphasis on ochratoxin producing species. Int. J. Food Microbiol. 2011, 145, 229-237. [CrossRef]

225. Fanelli, F.; Schmidt-Heydt, M.; Haidukowski, M.; Geisen, R.; Logrieco, A.; Mulè, G. Influence of light on growth, fumonisin biosynthesis and FUM1 gene expression by Fusarium proliferatum. Int. J. Food Microbiol. 2012, 153, 148-153. [CrossRef]

226. Ntagkas, N.; de Vos, R.C.; Woltering, E.J.; Nicole, C.; Labrie, C.; Marcelis, L.F. Modulation of the Tomato Fruit Metabolome by LED Light. Metabolites 2020, 10, 266. [CrossRef]

227. Loi, M.; De Leonardis, S.; Mulè, G.; Logrieco, A.F.; Paciolla, C. A Novel and Potentially Multifaceted Dehydroascorbate Reductase Increasing the Antioxidant Systems is Induced by Beauvericin in Tomato. Antioxidants 2020, 9, 435. [CrossRef]

228. Loi, M.; Paciolla, C.; Logrieco, A.F.; Mulè, G. Plant Bioactive Compounds in Pre-and Postharvest Management for Aflatoxins Reduction. Front. Microbiol. 2020, 11, 1-16. [CrossRef] [PubMed]

229. Hasan, M.; Bashir, T.; Ghosh, R.; Lee, S.K.; Bae, H. An overview of LEDs' effects on the production of bioactive compounds and crop quality. Molecules 2017, 22, 1420. [CrossRef] [PubMed]

230. Alsanius, B.W.; Karlsson, M.; Rosberg, A.K.; Dorais, M.; Naznin, M.T.; Khalil, S.; Bergstrand, K.J. Light and Microbial Lifestyle: The Impact of Light Quality on Plant-Microbe Interactions in Horticultural Production Systems-A Review. Horticulturae 2019, 5, 41. [CrossRef]

231. Nadalini, S.; Zucchi, P.; Andreotti, C. Effects of blue and red LED lights on soilless cultivated strawberry growth performances and fruit quality. Eur. J. Hortic. Sci. 2017, 82, 12-20. [CrossRef]

232. Díaz-Galián, M.V.; Torres, M.; Sanchez-Pagán, J.D.; Navarro, P.J.; Weiss, J.; Egea-Cortines, M. Enhancement of strawberry production and fruit quality by blue and red LED lights in research and commercial greenhouses. S. Afr. J. Bot. 2020. [CrossRef]

233. Lakhiar, I.A.; Gao, J.; Syed, T.N.; Chandio, F.A.; Buttar, N.A. Modern plant cultivation technologies in agriculture under controlled environment: A review on aeroponics. J. Plant Interact. 2018, 13, 338-352. [CrossRef]

234. Kim, H.J.; Yang, T.; Choi, S.; Wang, Y.J.; Lin, M.Y.; Liceaga, A.M. Supplemental intracanopy far-red radiation to red LED light improves fruit quality attributes of greenhouse tomatoes. Sci. Hortic. 2020, 261, 108985. [CrossRef] 